\title{
Serotonin-1A Autoreceptors Are Necessary and Sufficient for the Normal Formation of Circuits Underlying Innate Anxiety
}

\author{
Jesse W. Richardson-Jones, ${ }^{1}$ Caryne P. Craige, ${ }^{2}$ Thanh H. Nguyen, ${ }^{3}$ Hank F. Kung, ${ }^{4}$ Alain M. Gardier, ${ }^{3}$ Alex Dranovsky, ${ }^{1,6}$ \\ Denis J. David, ${ }^{3}$ Bruno P. Guiard, ${ }^{3}$ Sheryl G. Beck, ${ }^{2}$ René Hen, ${ }^{1,5,6}$ and E. David Leonardo ${ }^{1,6}$ \\ ${ }^{1}$ Department of Psychiatry, Columbia University, New York, New York 10032, ${ }^{2}$ Department of Anesthesiology, Children's Hospital of Philadelphia and \\ University of Pennsylvania, Philadelphia, Pennsylvania 19312, ${ }^{3}$ Faculté Pharmacie, Université Paris Sud, Chatenay-Malabry, F-92296 France, ${ }^{4}$ Department \\ of Radiology, University of Pennsylvania, Philadelphia, Pennsylvania 19104, ${ }^{5}$ Department of Neuroscience, Columbia University, New York, New York \\ 10032, and ${ }^{6}$ The New York State Psychiatric Institute, New York, New York 10032
}

Identifying the factors contributing to the etiology of anxiety and depression is critical for the development of more efficacious therapies. Serotonin (5-HT) is intimately linked to both disorders. The inhibitory serotonin-1A $\left(5-\mathrm{HT}_{1 \mathrm{~A}}\right)$ receptor exists in two separate populations with distinct effects on serotonergic signaling: (1) an autoreceptor that limits 5-HT release throughout the brain and (2) a heteroreceptor that mediates inhibitory responses to released 5-HT. Traditional pharmacologic and transgenic strategies have not addressed the distinct roles of these two receptor populations. Here we use a recently developed genetic mouse system to independently manipulate $5-\mathrm{HT}_{1 \mathrm{~A}}$ autoreceptor and heteroreceptor populations. We show that 5- $\mathrm{HT}_{1 \mathrm{~A}}$ autoreceptors act to affect anxiety-like behavior. In contrast, 5- $\mathrm{HT}_{1 \mathrm{~A}}$ heteroreceptors affect responses to forced swim stress, without effects on anxiety-like behavior. Together with our previously reported work, these results establish distinct roles for the two receptor populations, providing evidence that signaling through endogenous $5-\mathrm{HT}_{1 \mathrm{~A}}$ autoreceptors is necessary and sufficient for the establishment of normal anxiety-like behavior.

\section{Introduction}

Anxiety and depression are highly comorbid disorders with partially overlapping genetic predisposition, environmental risk, symptom dimensions, and treatment profiles (Ressler and Nemeroff, 2000; Nemeroff, 2002). This overlap suggests that anxiety and depression share some circuitry and neurochemistry, but can be influenced by distinct factors.

Serotonin (5-HT) participates in the etiology and treatment of both anxiety and depression (Rush et al., 2006; Davidson, 2009). The most common treatments for major depressive disorder and many anxiety disorders are the selective serotonin reuptake inhibitors (SSRIs), which are thought to exert their therapeutic effects by increasing extracellular 5-HT levels (Gartside et al., 1995). However, in contrast to the beneficial effects of SSRIs in adults, evidence from rodent models suggest that SSRI treatment during early development increases anxiety or depression later in life (Caspi et al., 2003; Lira et al., 2003; Ansorge et al., 2008;

Received Nov. 2, 2010; revised Feb. 11, 2011; accepted Feb. 23, 2011

Author contributions: J.W.R.J., A.M.G., A.D., D.J.D., S.G.B., R.H., and E.D.L. designed research; J.W.R.J., C.P.C., T.H.N., D.J.D., B.P.G., and E.D.L. performed research; H.F.K. contributed unpublished reagents/analytic tools; J.W.R.J., A.M.G., A.D., B.P.G., S.G.B., R.H., and E.D.L. analyzed data; J.W.R.J. and E.D.L. wrote the paper.

We thank Matheus Araujo for technical assistance. This work was supported by NIH Grants K08 MH076083 and R01 MH091427 to E.D.L., a NARSAD Young Investigator Award to E.D.L., R01 MH075047 to S.G.B, R01 MH068542 to R.H., a NARSAD Distinguished Investigator Award to R.H. and AstraZeneca Grant CU08-8439 to R.H.

R.H. receives compensation as a consultant for Braincells, in relation to the generation of novel antidepressants. E.D.L. receives compensation as a consultant from $P G X$ Health.

Correspondence should be addressed to either Dr. E. David Leonardo or René Hen, Department of Psychiatry, Columbia University/New York State Psychiatric Institute, 1051 Riverside Drive, Box 87, New York, New York 10032. E-mail: el367@columbia.edu or rh95@columbia.edu.

DOI:10.1523/JNEUROSCI.5836-10.2011

Copyright $\odot 2011$ the authors $\quad 0270-6474 / 11 / 316008-11 \$ 15.00 / 0$
Olivier et al., 2008; Oberlander et al., 2009). Thus, 5-HT may affect immature and mature mood-related circuitry differently.

Serotonin is released throughout the forebrain by axons emanating from cell bodies located in the midbrain raphe (Barnes and Sharp, 1999). The largely neuromodulatory effects of 5-HT are mediated through 14 receptor subtypes, whereas 5 -HT levels are limited by two inhibitory autoreceptors expressed on 5-HT raphe neurons (Barnes and Sharp, 1999). The 5-HT $\mathrm{HA}_{1 \mathrm{~A}}$ receptor, a major inhibitory receptor subtype, is expressed on 5-HT raphe neurons as an autoreceptor, limiting released 5-HT at nerve terminals, and in diverse target regions as a heteroreceptor mediating cellular responses to released 5-HT. In particular, 5- $\mathrm{HT}_{1 \mathrm{~A}}$ heteroreceptors are highly expressed in forebrain regions that regulate mood and anxiety, such as the prefrontal cortex, hippocampus, and amygdala (Hamon et al., 1990; Beck et al., 1992; Riad et al., 2000). Thus, the $5-\mathrm{HT}_{1 \mathrm{~A}}$ receptor can influence anxiety or depression by impacting either 5-HT levels (as an autoreceptor) or the limbic response to released 5-HT (as a heteroreceptor).

Diverse evidence has demonstrated that $5-\mathrm{HT}_{1 \mathrm{~A}}$ receptors contribute to the establishment of mood disorders. A functional polymorphism in the promoter region of the human Htrla gene (coding for the human $5-\mathrm{HT}_{1 \mathrm{~A}}$ receptor) that regulates receptor levels is linked to depression, response to antidepressants, and amygdala reactivity (Lemonde et al., 2003; Le François et al., 2008; Fakra et al., 2009). Mice lacking all 5- $\mathrm{HT}_{1 \mathrm{~A}}$ receptors throughout life display increased anxiety-like behavior (Heisler et al., 1998; Parks et al., 1998; Ramboz et al., 1998), an effect that is phenocopied by pharmacological blockade during the first few postnatal weeks (Lo Iacono and Gross, 2008). Transgenic gain- 
of-function studies have likewise suggested that the $5-\mathrm{HT}_{1 \mathrm{~A}}$ receptor can stably impact anxiety-like behavior during the first weeks of life (Gross et al., 2002; Bert et al., 2006). Given this evidence, $5-\mathrm{HT}_{1 \mathrm{~A}}$ receptors may influence anxiety and depression differentially not only between subpopulations, but also across developmental stages in an animal.

Separating both the temporal (developmental vs adult) and spatial (autoreceptor vs heteroreceptor) roles of the endogenous $5-\mathrm{HT}_{1 \mathrm{~A}}$ receptor in anxiety and depression has proven difficult with existing genetic or pharmacological techniques. To independently assess the functional role of endogenous $5-\mathrm{HT}_{1 \mathrm{~A}}$ autoreceptors and heteroreceptors, we developed a genetic mouse system with temporal and spatial specificity and tested the adult phenotype of these animals in a number of classic, mood-related paradigms.

\section{Materials and Methods}

Transgenic mice

5- $\mathrm{HT}_{1 \mathrm{~A}}$ autoreceptor knock-out mice. Mice with suppressible 5- $\mathrm{HT}_{1 \mathrm{~A}}$ receptors $\left(\mathrm{Htrla}^{\text {tetO }}\right)$ were bred as described previously (Richardson-Jones et al., 2010). Htr1 $a^{\text {tetO/tetO }}$ mice demonstrate a pattern of 5-HT 1 receptors that is indistinguishable from the wild-type pattern. Mice with inducible suppression of 5- $\mathrm{HT}_{1 \mathrm{~A}}$ autoreceptors were homozygous for the tetO insertion $\left(\mathrm{Htrl} a^{\text {tetO/tetO }}\right)$, possessed one copy of the raphe-specific tTS suppressor transgene, Pet1-tTS, and were maintained in the absence of doxycycline (dox) throughout life (Richardson-Jones et al., 2010).

5-HT $\mathrm{T}_{1 \mathrm{~A}}$ heteroreceptor knock-out mice. Heteroreceptor-specific suppression was achieved by placing tTS under transcriptional control of elements of the $\alpha$-CaMKII promoter (Mayford et al., 1996). Briefly, an EcoRI-BamHI fragment containing the tTS coding sequence was freed from the pAct tTS plasmid (Mallo et al., 2003). The fragment was blunted and cloned into the EcoRV site of the pNN265 plasmid, flanking it with a generic 5 ' intron, 3 ' intron, and SV40 polyA sequence (Mayford et al., 1996). The tTS sequence flanked by introns was freed by digest with Not1 and cloned into the pMM403 plasmid, placing it under the control of $\alpha$-CaMKII promoter fragments. Lastly, the promoter fragments and tTS coding sequence (CamK-tTS) were freed by Sfi/Srf digest and subjected to pronuclear injection into B6CBA/F2 hybrid zygotes. Founders were screened by PCR for tTS as described previously (Richardson-Jones et al., 2010) and by Southern blot analysis.

Seven founder lines were generated, bred to the Htrla $a^{\text {tetO/tetO }}$ background, and screened for suppression of $5-\mathrm{HT}_{1 \mathrm{~A}}$ heteroreceptors. The three general patterns of suppression in these lines corresponded to the previous reported activity of these promoter fragments: (1) suppression of all receptors in the brain, (2) preferential suppression of forebrain receptors while sparing receptors in the raphe, and (3) preferential suppression of dorsal hippocampal receptors while sparing most other receptor populations (data not shown) (Gross et al., 2002; Pittenger et al., 2002). One line was identified that displayed suppression of $5-\mathrm{HT}_{1 \mathrm{~A}}$ heteroreceptors without affecting autoreceptors, and this line was used for subsequent experiments. Mice with inducible suppression of 5- $\mathrm{HT}_{1 \mathrm{~A}}$ heteroreceptors were homozygous for the tetO insertion $\left(\mathrm{Htrla}^{\text {tetO/tetO}}\right)$, possessed one copy of the forebrain-specific tTS suppressor transgene CamK-tTS, and were maintained in the absence of dox throughout life.

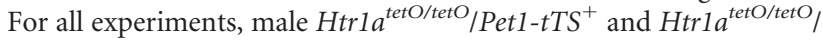
CamK-tTS ${ }^{+}$mice were bred to $H \operatorname{trl} a^{\text {tetO/tetO }}$ females. Thus, the tTS transgene was transmitted through the male germline, ensuring that all pups were raised by mothers of the same genotype, regardless of dox status. All experiments were conducted on male offspring. Animals were maintained on a mixed 129S6/Sv, C57B6, CBA background. To control for the effect of transgene insertion and genetic background, controls for all experimental groups were generated by feeding $\mathrm{H} t r 1 a^{\text {tetO/tetO }}$ / Pet1-tTS ${ }^{+}$or $\mathrm{Htrla}^{\text {tetO/tetO }} / \mathrm{CamK}-\mathrm{TS}^{+}$animals chow containing 40 $\mathrm{mg} / \mathrm{kg}$ dox (product \#F5545; Bioserv) throughout life. Dox exposure in utero in these animals was accomplished by feeding mothers with the dox chow throughout the course of breeding. Experimental animals were fed standard laboratory chow (Prolab Isopro RMH 3000; PMI Nutrition
International) either throughout life [autoreceptor-knock-out (auto$\mathrm{KO}$ ) and heteroreceptor-knock-out (hetero-KO)] or beginning at postnatal day 50 (adult hetero-KO). To control for the possible effects of dox on behavior, littermate controls lacking the tTS transgene, in which dox had no effect on $5-\mathrm{HT}_{1 \mathrm{~A}}$ receptor expression, were also tested in baseline behavioral experiments. For all tests presented, dox exposure alone did not result in any behavioral changes (data not shown).

\section{Animal husbandry}

Animals were housed in groups of three to five per cage and had ad libitum access to food and water. Animals were maintained on a 12:12 light/dark schedule; all testing was conducted during the light period. Animal protocols were approved by the Institutional Animal Care and Use Committee and were conducted in accordance to the NIH Guide for the Care and Use of Laboratory Animals. Care was taken to minimize the number of animals used and their suffering.

\section{Receptor autoradiography}

Mice were killed by cervical dislocation and decapitation. Extracted brains were frozen immediately on crushed dry ice $\left(-75^{\circ} \mathrm{C}\right)$ and maintained at $-80^{\circ} \mathrm{C}$ until sectioning. Brains were cryosectioned at a thickness of $18 \mu \mathrm{m}$ and sections were thaw-mounted on Superfrost slides (Fisher Scientific). Sections were maintained at $-80^{\circ} \mathrm{C}$ until processing. Mounted sections were processed for 4-(2'-methoxyphenyl)-1-[2'-(n2 "-pyridinyl)-p-[ $\left.{ }^{125} \mathrm{I}\right]$ iodobenzamido] ethylpiperazine ( $\left.{ }^{125} \mathrm{I}-\mathrm{MPPI}\right)$ autoradiography and receptor levels were quantified using a previously described method (Richardson-Jones et al., 2010).

\section{Electrophysiology}

Whole-cell recordings of dorsal raphe and hippocampal CA1 pyramidal neurons were made as previously described (Beck et al., 2004; Tsetsenis et al., 2007; Crawford et al., 2010). In brief, mice were killed using decapitation. While submerged in a cold artificial CSF (aCSF) solution where $\mathrm{NaCl}$ had been replaced with sucrose $(248 \mathrm{~mm})$, the coronal slices were cut at the level of the dorsal hippocampus and midbrain with a VT1000s vibratome (Leica Microsystems) to generate $200 \mu \mathrm{m}$ thick brain slices. Slices were maintained in aCSF bubbled with $95 \% \mathrm{O}_{2} / 5 \% \mathrm{CO}_{2}$ at $36^{\circ} \mathrm{C}$ for $1 \mathrm{~h}$ and then at room temperature until used. Individual slices were then placed in a recording chamber and continuously perfused with $32-34^{\circ} \mathrm{C}$ aCSF solution bubbled with $95 \% \mathrm{O}_{2} / 5 \% \mathrm{CO}_{2}$ with a solution flow rate of $1.5-2 \mathrm{ml} / \mathrm{min}$. The composition of the aCSF was as follows (in $\mathrm{mM}$ ): 124 $\mathrm{NaCl}, 2.5 \mathrm{KCl}, 1.25 \mathrm{NaH}_{2} \mathrm{PO}_{4}, 2.0 \mathrm{MgSO}_{4}, 2.5 \mathrm{CaCl}_{2}, 10$ dextrose, and 26 $\mathrm{NaHCO}_{3}$. Neurons were visualized using Nikon E600 (Optical Apparatus) upright microscope fitted with a $40 \times$ water-immersion objective, differential interference contrast, and infrared filter. Whole-cell recording pipettes fabricated on a pipette puller (P-97; Sutter Instrument) had a resistance of 6-10 $\mathrm{M} \Omega$ when filled with an intracellular solution containing the following (in $\mathrm{mm}$ ): $130 \mathrm{~K}$-gluconate, $5 \mathrm{NaCl}, 10 \mathrm{Na}$ phosphocreatinine, $1 \mathrm{MgCl}_{2}, 0.02$ EGTA, 10 HEPES, $2 \mathrm{MgATP}, 0.5$ $\mathrm{Na}_{2} \mathrm{GTP}$, and $0.1 \%$ biocytin, $\mathrm{pH}$ 7.3. Recordings were collected online with a Multiclamp 700B amplifier, Digidata 1320 A/D converter, and Clampex 9.0 software (Molecular Devices). In current-clamp recording, resting membrane potential, action potential (AP) threshold, AP duration, after-hyperpolarization (AHP) amplitude, and the time it takes for the AHP to depolarize to one-half its peak amplitude were measured directly from traces, as previously described (Crawford et al., 2010). In voltage clamp, with a holding potential of $-60 \mathrm{mV}$, the magnitude of the outward current elicited by bath application of $100 \mathrm{~nm} 5$-carboxyamidotryptamine (5-CT) was measured. 5-CT was chosen for these experiments instead of $8-\mathrm{OH}-\mathrm{DPAT}$ as it is a high affinity full agonist, is less lipophillic, and washes out more easily from the slices. Following the experiment, slices were fixed for $2-3 \mathrm{~h}$ with $4 \%$ paraformaldehyde and the midbrain slices were processed for immunohistochemical detection of tryptophan hydroxylase (TPH). Identity of all recorded cells was confirmed by visualization of the biocytin-filled cells. Immunohistochemical identification of each neuron recorded in patch-clamp configuration was completed as previously described (Beck et al., 2004; Lemos et al., 2006; Kirby et al., 2008). In brief, a standard immunohistochemistry protocol was used on $200-\mu \mathrm{m}$-thick slices using mouse anti-TPH (1:200; Sigma) along with secondary donkey anti-mouse Alexa Fluor 
488 (1:200; Invitrogen). Biocytin-filled cells were visualized with streptavidin-conjugated Alexa Fluor G38 (1:100; Invitrogen). These cells were also labeled with NeuN (1:500; Sigma), which was visualized with a donkey anti-mouse Alexa Fluor 488 (1:200, Invitrogen) secondary antibody. TPH labeling of biocytin-filled cells was imaged on a DMR fluorescent microscope (Leica Microsystems) using OpenLab 3.0.9 software (Improvision) and confirmed on a DMIRE2 confocal microscope (Leica Microsystems) using confocal software (version 2.5; Leica Microsystems).

\section{Intracerebral in vivo microdialysis}

Extracellular 5-HT levels were measured by in vivo microdialysis as previously described (Guiard et al., 2008). Briefly, two concentric dialysis probes were implanted in the ventral hippocampus (vHPC) and prefrontal cortex (PFC) (outer diameter by active length: $0.3 \times 1.6 \mathrm{~mm}$ and $0.3 \times 2 \mathrm{~mm}$, respectively) of anesthetized mice (chloral hydrate, 400 $\mathrm{mg} / \mathrm{kg}$, i.p.). Stereotaxic coordinates were as follows (in mm): PCF: anterior, 1.6; lateral, 1.3; ventral, 1.6; vHPC: anterior, -2.8; lateral, 3.0; ventral, 3.0 (Franklin and Paxinos, 1997). Animals were allowed to recover for a period of $24 \mathrm{~h}$. Following recovery, probes were continuously perfused with aCSF, and dialysates were collected every $15 \mathrm{~min}$ for analysis by HPLC-amperometry (Guiard et al., 2008). Baseline 5-HT levels were calculated as the average of the first four samples, \pm SEM. Freely moving mice were treated $(t=0)$ with either a challenge dose of fluoxetine (18 mg/kg; i.p.) or its vehicle, and dialysate samples were collected for a $0-120 \mathrm{~min}$ post-treatment period. The limit of sensitivity for 5 -HT was $0.5 \mathrm{fmol} / \mathrm{sample}$ (signal-to-noise ratio, 2). Following sample collection, brains were removed and sectioned to ensure proper probe placement.

\section{Behavioral and physiological testing}

All animals used for behavioral testing were age matched within 2 weeks. Animals were initially tested at 11-13 weeks of age, at least 4 weeks after the cessation of dox in adult heteroreceptor-KO animals. Baseline anxiety tests were completed before other behavioral tests.

8-OH-DPAT-induced hypothermia. Body temperature was assessed intrarectally using a lubricated probe inserted $\sim 2 \mathrm{~cm}$ and a Thermalert TH-5 thermal monitor (Physitemp). Mice were singly housed in clean cages for $10 \mathrm{~min}$ and three baseline body temperature measurements were taken. Ten minutes after the third baseline measurement, animals received 8-OH-DPAT intraperitoneally at the doses indicated and body temperature was monitored every $10 \mathrm{~min}$ for a total of $50 \mathrm{~min}$. Temperatures are represented as a change from the final baseline measurement.

Stress-induced hyperthermia. The stress-induced hyperthermia paradigm measures a physiologic response to a stressful stimulus (Adriaan Bouwknecht et al., 2007). Briefly, animals in their home cages were moved to a testing room and allowed to acclimate for $1 \mathrm{~h}$. One animal per cage was removed and a baseline body temperature was measured intrarectally. Each animal was then placed in a novel, clean cage for $10 \mathrm{~min}$, after which a second body temperature was recorded.

Open-field test. Exploration in response in response to a novel open field was measured as described previously (Richardson-Jones et al., 2010). Dependent measures were total path length (in $\mathrm{cm}$ ), number, and percentage of distance in the center (distance traveled in the center divided by the total distance traveled).

Light/dark choice test. Exploration of the light/dark chamber was measured as described previously (Richardson-Jones et al., 2010). Dependent measures were total distance and percentage of time spent in the light compartment.

Modified forced-swim test. Behavioral response to forced swimming was assayed as described previously (David et al., 2007). Briefly, mice were placed into clear plastic buckets $20 \mathrm{~cm}$ in diameter and $23 \mathrm{~cm}$ deep, filled two-thirds of the way up with $26^{\circ} \mathrm{C}$ water and videotaped from the side. Mice had a 2 min pretest period before initiating scoring, after which two consecutive 2 min periods were scored. All animals were exposed to the swim test on two consecutive days. Scoring was done using an automated Viewpoint Videotrack software package. Dependent variables were immobility, swimming, and climbing.

\section{Statistical analysis}

In general, the effect of treatment or dose was analyzed using an ANOVA, using repeated measures where appropriate. Significant ANOVAs were followed up with Fisher protected least significant difference test for behavioral and physiological measures, and with Student-NeumanKeuls $t$ test for electrophysiological characterization.

\section{Results \\ Conditional suppression of the $5-\mathrm{HT}_{1 \mathrm{~A}}$ autoreceptors and heteroreceptors}

Previous attempts to target autoreceptor versus heteroreceptor populations independently in mice relied on transgenic gain-offunction strategies using heterologous promoters that resulted in overexpression and misexpression of the receptor (Gross et al., 2002; Kusserow et al., 2004; Bert et al., 2006; Audero et al., 2008). Such approaches fall short of establishing causal links between endogenous receptor populations and either circuit function or behavior. To independently manipulate either $5-\mathrm{HT}_{1 \mathrm{~A}}$ heteroreceptors or autoreceptors while maintaining endogenous expression of the other receptor population, we used the tTS/tetO system to suppress $5-\mathrm{HT}_{1 \mathrm{~A}}$ receptor transcription from the Htrla gene locus. We previously reported the generation of mice that allow for specific suppression of 5- $\mathrm{HT}_{1 \mathrm{~A}}$ autoreceptors, using two engineered mouse lines: a raphe-specific tTS transgenic line and a knock-in mouse line with tetO sites inserted between the promoter and coding regions of the Htr1A locus (Richardson-Jones et al., 2010). To suppress $5-\mathrm{HT}_{1 \mathrm{~A}}$ autoreceptors in the raphe throughout life (auto-KO), the previously described Htrlato/tetO/ Pet1-tTS ${ }^{+}$mice were maintained in the absence of dox throughout life (Fig. 1C,D). Controls for these mice, in which $5-\mathrm{HT}_{1 \mathrm{~A}}$ autoreceptors were not suppressed, were generated by maintaining $\mathrm{Htrla} \mathrm{a}^{\text {tetO/tetO }} / \mathrm{Pet}^{-} \mathrm{TTS}^{+}$mice in the presence of dox throughout life (Fig. $1 A, D$ ). Quantitative receptor autoradiography revealed that $\angle 20 \%$ of control $5-\mathrm{HT}_{1 \mathrm{~A}}$ receptor binding remained in the dorsal raphe of adult auto-KO mice (one-tailed $t$ test in the dorsal raphe, $t_{13}=-15.503, p<$ $0.0001)$, whereas no changes were observed in binding of $5-\mathrm{HT}_{1 \mathrm{~A}}$ in areas of high heteroreceptor expression, such as the amygdala, hippocampus, and entorhinal cortex (repeatedmeasures ANOVA with brain region as a within-subject factor and group as a between-subject factor, main effect of group $F_{(1,13)}=1.398, p=0.2583$; region-by-group interaction, $F_{(1,13)}=0.795, p=0.46232$ ) (Fig. 2). Attempts with this line to fully suppress the autoreceptor beginning in adulthood resulted in a modest $30 \%$ reduction in raphe $5-\mathrm{HT}_{1 \mathrm{~A}}$ expression. Physiological and behavioral characterization of these animals has been reported previously (Richardson-Jones et al., 2010). The reason for more effective suppression of $5-\mathrm{HT}_{1 \mathrm{~A}}$ transcription in animals maintained in the absence of dox throughout life remains unclear, although it appears that early developmental suppression at the $5-\mathrm{HT}_{1 \mathrm{~A}}$ locus may be irreversible (data not shown).

To generate mice with suppression of $5-\mathrm{HT}_{1 \mathrm{~A}}$ heteroreceptors without affecting autoreceptors, we first created a transgenic mouse line with tTS expression directed by promoter elements from the $\alpha$-CaMKII gene (Mayford et al., 1996). One mouse line was identified that demonstrated suppression of only $5-\mathrm{HT}_{1 \mathrm{~A}}$ forebrain heteroreceptors without affecting 5- $\mathrm{HT}_{1 \mathrm{~A}}$ raphe autoreceptors (hetero-KO) (ANOVA in dorsal raphe, $F_{(2,9)}=0.429$, $p<0.6635$ ) (Figs. $1 B, E ; 2 B, D$ ). In hetero-KO mice, receptor expression was undetectable in the hippocampus, amygdala, or prefrontal cortex, whereas low levels of receptor remained in the olive, entorhinal cortex, and the medial and lateral septum 
A Htr1 $a^{\text {teto/teto }}$ Pet1-tTS $S^{+}$or CamK-tTS
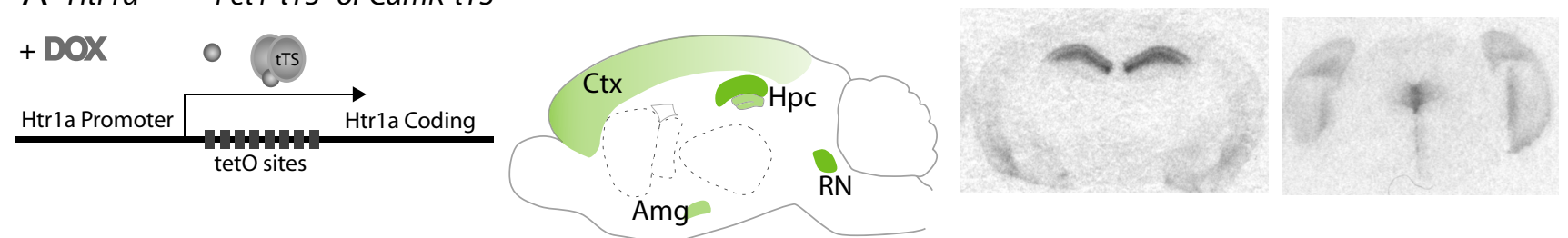

B Htr1a ${ }^{\text {teto/teto }}$ CamK-tTS
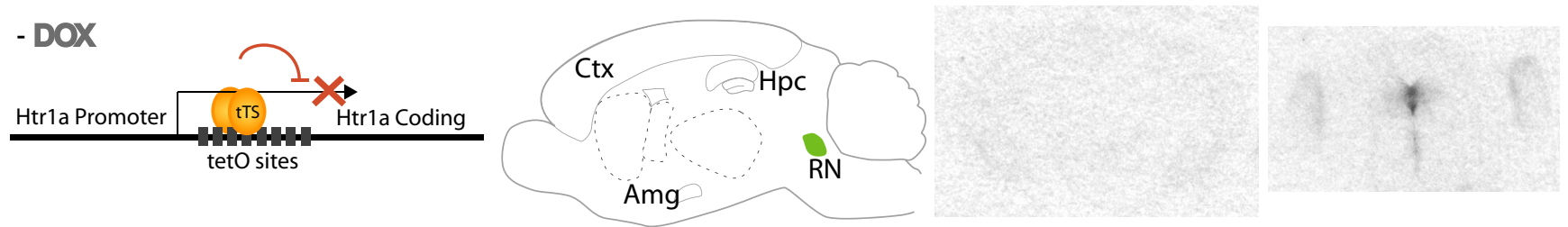

C Htr1 $a^{\text {teto/teto }}$ Pet1-tTS
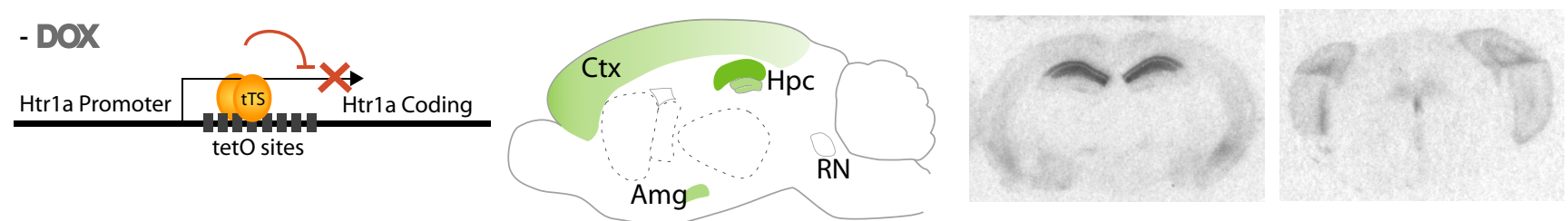

D

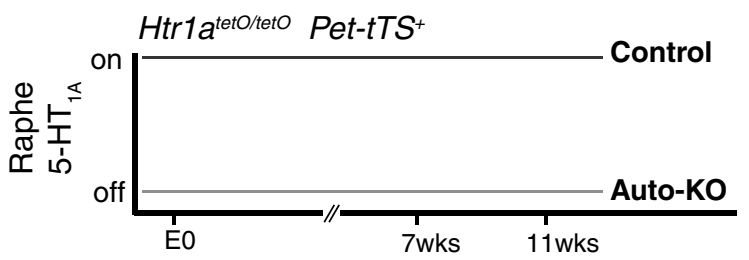

E

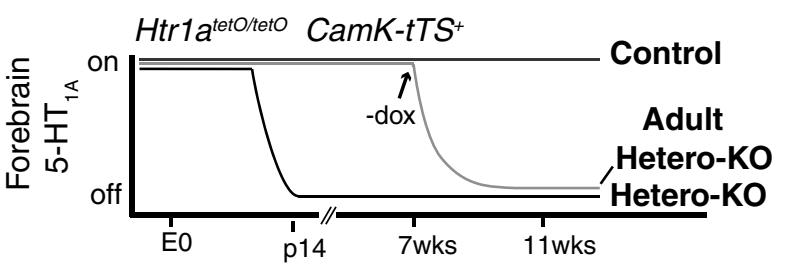

Figure 1. A, Adult mice homozygous for the regulatable $\mathrm{Htr} 1 \mathrm{a}^{\text {teto }}$ allele and possessing one copy of a tTS transgene express 5 - $\mathrm{HT}_{1 \mathrm{~A}}$ receptors in normal patterns in the brain when maintained on doxycycline, assessed by ${ }^{125} \mathrm{I}-\mathrm{MPPI}$ autoradiography and shown in coronal sections at the level of the hippocampus and raphe nucleus. A schematic of normal 5 - $\mathrm{HT}_{1 \mathrm{~A}}$ receptor binding in the sagittal plane is shown for reference. $B$, Adult mice homozygous for the regulatable $H t r 1 a^{\text {teto }}$ allele and possessing one copy of the $\alpha$-CaMKII-tTS transgene express 5 -HT 1 A raphe autoreceptors normally, but show almost no binding of forebrain receptors when maintained in the absence of doxycycline. $C$, Adult mice homozygous for the regulatable $H$ tr $1 a^{\text {teto }}$ allele and possessing one copy of the Pet1-tTS transgene express 5- $\mathrm{HT}_{1 \mathrm{~A}}$ forebrain heteroreceptors normally, but show almost no binding of raphe autoreceptors when maintained in the absence of doxycycline. $\boldsymbol{D}$, Mice lacking 5 -HT $1 \mathrm{~A}$ autoreceptors (auto-KO) and mice with autoreceptors intact (control) were generated by maintaining $H$ tr $1 a^{\text {tetO/teto }}$ Pet1-tTS ${ }^{+}$mice in the absence or presence of doxycycline throughout life. $E$, Mice lacking 5- $\mathrm{HT}_{1 \mathrm{~A}}$ heteroreceptors (hetero-KO) and mice with heteroreceptors intact (control) were generated by maintaining $\mathrm{Htr}^{\text {teto/teto }} \alpha \mathrm{CaMKII}^{\mathrm{t} T \mathrm{~S}^{+}}$mice in the absence or presence of doxycycline throughout life. Mice lacking heteroreceptors beginning in adulthood (adult hetero-K0) were maintained on doxycycline until 7 weeks of age. Ctx, Cortex; Amg, amygdala; Hpc, hippocampus; RN, raphe nucleus; E0, day 0; p14; postnatal day 14.

(ANOVA for the effect of group in hippocampus, $F_{(2,9)}=20,210$; $p<0.0001$ ) (Fig. $2 B, D$ ). Consistent with the expected delayed developmental activation of the $\alpha$-CaMKII promoter elements, we confirmed that suppression of receptors was complete by postnatal day 14 (Fig. $2 \mathrm{E}$ ). Control mice, in which $5-\mathrm{HT}_{1 \mathrm{~A}}$ heteroreceptors were not suppressed, were generated by maintaining $\mathrm{Htrla} \mathrm{a}^{\text {tetO/tetO}} / \mathrm{CaMKII-tS^{+ }}$ mice in the presence of dox throughout life (Fig. $1 E$ ). Adult suppression of 5- $\mathrm{HT}_{1 \mathrm{~A}}$ heteroreceptors (adult hetero-KO) was achieved by maintaining Htrla $a^{\text {tetO/tetO }} /{\mathrm{CaMKII}-t \mathrm{TS}^{+}}$mice in the presence of dox until postnatal day 50 , then withdrawing dox for at least 4 weeks. Adult suppression of $5-\mathrm{HT}_{1 \mathrm{~A}}$ receptors in these animals was as effective as early developmental suppression (Figs. $1 E, 2 B, D$ ).

\section{Altered agonist response in mice with conditional} suppression of $5-\mathrm{HT}_{1 \mathrm{~A}}$ autoreceptors and heteroreceptors To directly confirm the functional impact of receptor suppression revealed by autoradiography, we performed whole-cell recordings of neurons in acute slice in response to the $5-\mathrm{HT}_{1,7}$ agonist 5-CT. Cellular responses were recorded in the dorsal raphe of auto-KO mice and their controls and in area CA1 of the hippocampus in hetero-KO mice and their controls. Following recording, cells were filled with biocytin. Pyramidal neurons in the hippocampus were confirmed by morphological features and raphe neurons were confirmed as serotonergic by immunohistochemistry for tryptophan hydroxylase (data not shown).

In agreement with the decreased $5-\mathrm{HT}_{1 \mathrm{~A}}$ autoreceptor levels indicated by autoradiography, serotonergic neurons in the dorsal raphe of auto-KO mice had a significantly decreased current response to 5 -CT (two-tailed $t$ test, $t_{35}=8.432, p<0.0001$ ) (Fig. $3 A-C)$. Indeed, we were unable to detect any response to $5-\mathrm{CT}$ (defined as current $<5 \mathrm{pA}$ ) in 5-HT dorsal raphe neurons of auto-KO mice, consistent with a lack of functional $5-\mathrm{HT}_{1 \mathrm{~A}}$ raphe autoreceptors in these animals. The small amount of remaining 

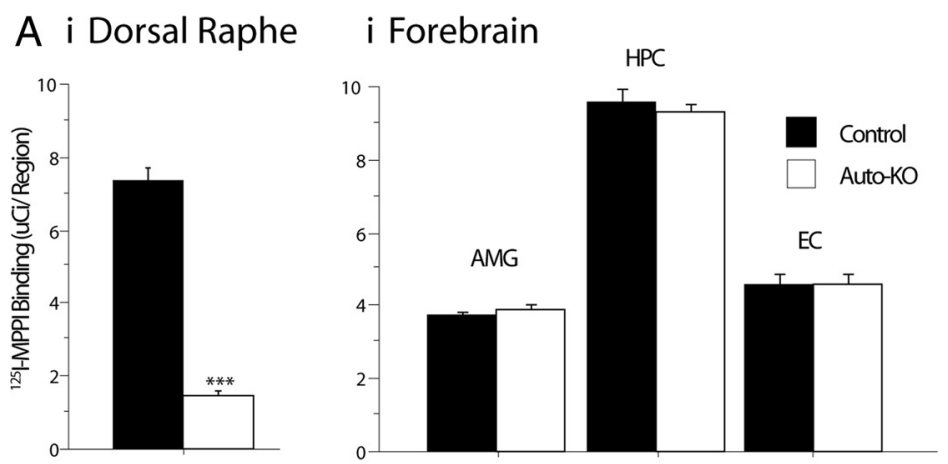

B i Dorsal Raphe

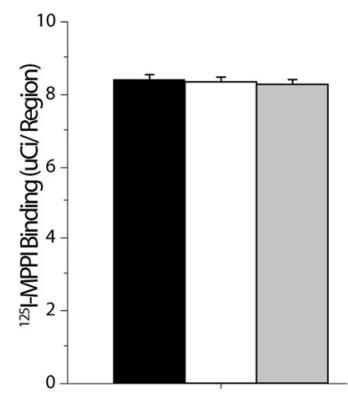

ii Forebrain

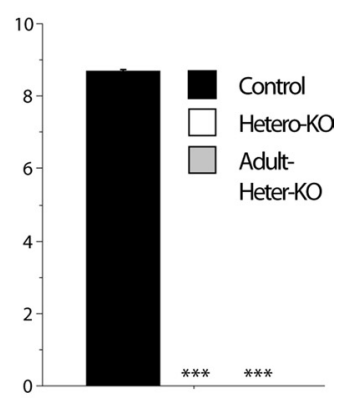

C Htr1 $a^{\text {teto/teto }}$ Pet1-tTS

+ Dox all life

(Control)
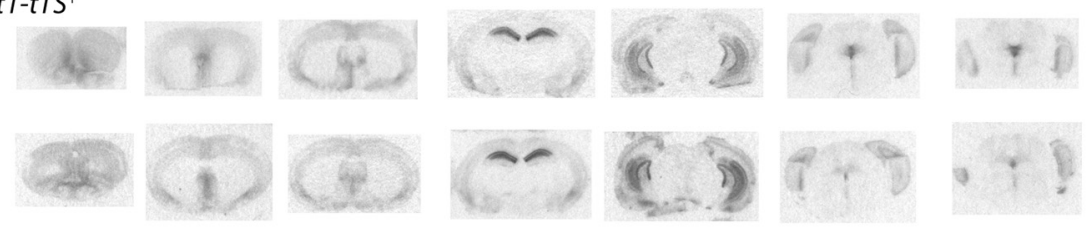

-Dox all life
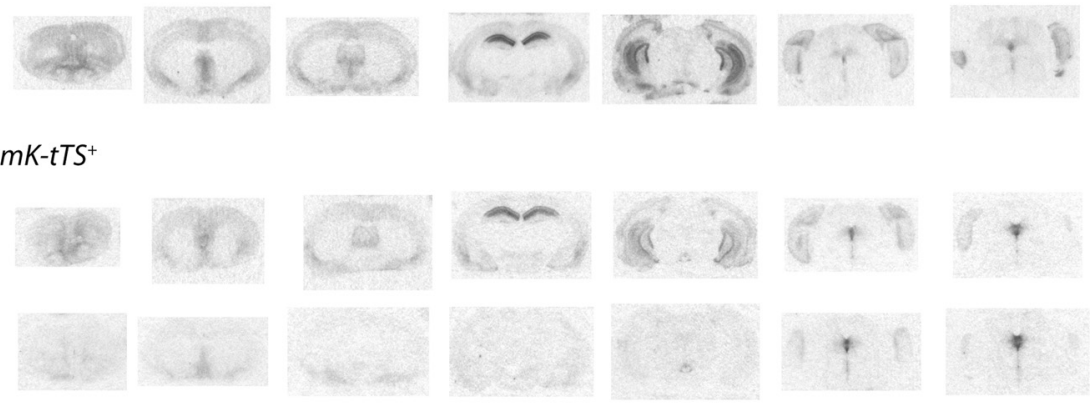

-Dox all life
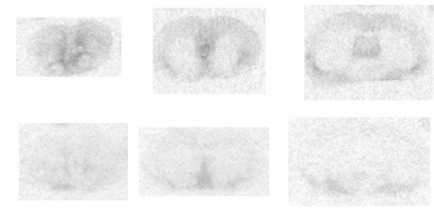

-Dox p50

(Adult-

Hetero-KO)
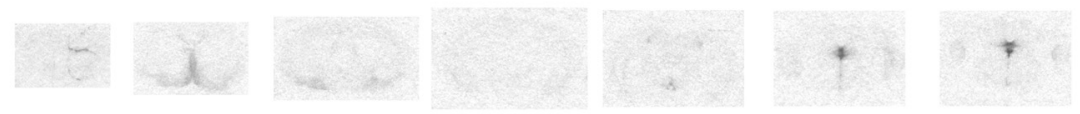

$\mathrm{E}$

Control

Hetero-KO
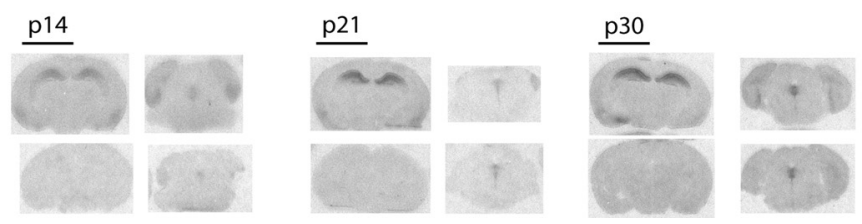

Figure 2. A, Quantitative ${ }^{125} \mathrm{I}-\mathrm{MPPI}$ autoradiography for $5-\mathrm{HT}_{1 \mathrm{~A}}$ receptors revealed a significant decrease in the dorsal raphe (i) of auto-K0 mice compared with their matched controls. Conversely, no difference was detected in forebrain regions (ii), such as the ventral dentate gyrus of the hippocampus (HPC), the amygdala (AMG), and the entorhinal cortex (EC). $\boldsymbol{B}, \boldsymbol{i}$, No difference was detected in binding in the dorsal raphe of hetero-KO or adult hetero-KO mice compared with their matched controls. ii, Conversely, binding was significantly decreased in dorsal CA1 of the hippocampus in both groups compared with control $\left(N=3-7 /\right.$ group). All values are mean \pm SEM. ${ }^{* * *} p<0.0001$. C, $D$, Matched autoradiograms showing detailed expression patterns of $5-\mathrm{HT}_{1 \mathrm{~A}}$ receptors binding across the rostrocaudal extent of the brain in coronal section comparing auto-KO mice and their controls $(\boldsymbol{C})$ and hetero-KO and adult hetero-KO mice and their controls $(\boldsymbol{D})$. Low levels of heteroreceptors remain in parts of the septum, olivary nucleus, and entorhinal cortex. $\boldsymbol{E}$, Receptor binding in the postnatal developmental period in hetero-KO mice and their controls. Matched sections are shown at the level of the dorsal hippocampus and the dorsal raphe nucleus. Forebrain receptor suppression is complete by postnatal day (p) 14 .

receptor binding in the dorsal raphe may represent either desensitized 5-HT $1 \mathrm{~A}$ autoreceptors or receptors on non-5-HT raphe neurons (Kirby et al., 2003; Beck et al., 2004).

In pyramidal neurons in area CA1 of hetero-KO mice, we observed a large decrease in the average current response to 5-CT (one-tailed $t$ test, $t_{39}=-3.254, p=0.0012$ ) (Fig. 3D-F), consistent with the greatly decreased levels of heteroreceptor revealed by autoradiography.

To assess the in vivo functional status of $5-\mathrm{HT}_{1 \mathrm{~A}}$ autoreceptors in both groups of mice, we examined their hypothermic response to challenge with the $5-\mathrm{HT}_{1 \mathrm{~A}}$ agonist $8-\mathrm{OH}-\mathrm{DPAT}$ or its saline vehicle. The controls for the auto-KO, hetero-KO, and adult hetero-KO mice displayed a hypothermic response to $0.5 \mathrm{mg} / \mathrm{kg}$ 8-OH-DPAT consistent with previously observed values (repeatedmeasures ANOVA, main effect of dose for hetero-KO controls, $F_{(1,12)}=46.979, p<0.0001$; adult hetero-KO controls, $F_{(1,9)}=$ 33.055, $p=0.0003$; auto-KO controls, $F_{(1,6)}=109.630, p<$
0.0001) (Fig. 4Aii,Bii,Cii). Consistent with a lack of functional autoreceptor, 5- $\mathrm{HT}_{1 \mathrm{~A}}$ auto-KO mice displayed no detectable body temperature decrease in response to 8-OH-DPAT, with responses indistinguishable from the response to saline injection (repeated-measures ANOVA for effect of treatment, $F_{(1,6)}=1.38$, $p=0.284$ ) (Fig. 4Ci). Conversely, 5- $\mathrm{HT}_{1 \mathrm{~A}}$ hetero-KO mice displayed a full hypothermic response to $8-\mathrm{OH}-\mathrm{DPAT}$ that was significantly different from the response to saline and indistinguishable from the hypothermic response in their controls (repeated-measures ANOVA, effect of dose in hetero-KO mice, $F_{(1,12)}=33.10, p<0.0001$; repeated-measures ANOVA, effect of group in 8 -OH-DPAT-treated mice, $F_{(1,12)}=2.486, p=0.141$ ) (Fig. $4 A$ ). Likewise, $5-\mathrm{HT}_{1 \mathrm{~A}}$ adult hetero- $\mathrm{KO}$ mice displayed a response to 8-OH-DPAT that was significantly different from the response to saline and indistinguishable from the response in their matched controls (repeated-measures ANOVA, effect of dose in adult hetero-KO mice, $F_{(1,9)}=36.216, p=0.0002$; repeated-measures ANOVA effect 
A

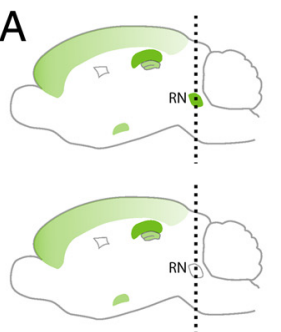

B

Control

Auto-KO
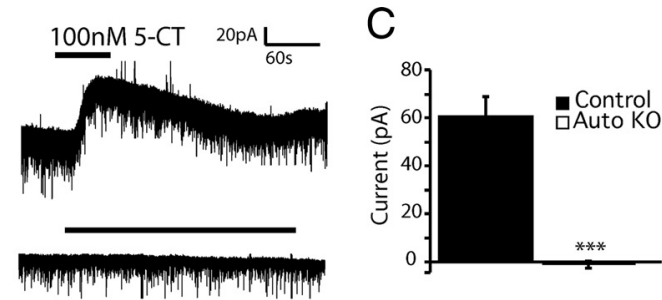

$\mathrm{D}$

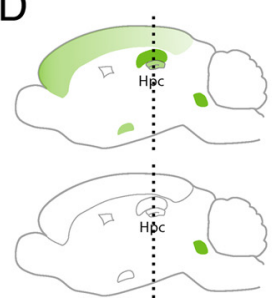

$\mathrm{E}$

Control

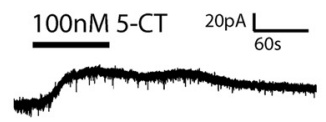

Hetero-KO
Figure 3. $A$, Schematic depicting level of sections taken for slice recordings in the dorsal raphe of auto-K0 mice. $\boldsymbol{B}$, Representative current traces from whole-cell recordings in the dorsal raphe of auto-KO mice and their controls in response to 5 -CT. C, Mean outward current amplitude in response to $100 \mathrm{~nm} 5-\mathrm{CT}$ was decreased in auto-KO mice. Values are mean $\pm \mathrm{SEM}(\mathrm{N}=12-24$ / group). D, Schematic depicting level of sections taken for slice recordings in CA1 of the hippocampus in hetero-KO mice. $\boldsymbol{E}$, Representative current traces from whole-cell recordings in CA1 hippocampal pyramidal cells of hetero-KO mice and their controls in response to the $5-\mathrm{HT}_{1 \mathrm{~A} / 7}$ agonist $5-\mathrm{CT} . \boldsymbol{F}$, Mean outward current amplitude in response to $100 \mathrm{~nm}$ 5-CT was decreased in hetero- $\mathrm{K} 0$ mice. Values are mean \pm SEM $(N=19-22 /$ group $) .{ }^{* *} p=0.01,{ }^{* * *} p<0.0001$. Hpc, Hippocampus; RN, raphe nucleus.
Thus, as expected, both control and auto-KO mice displayed increased $5-\mathrm{HT}_{\text {ext }}$ in response to acute treatment with the fluoxetine in the vHPC (Fig. $5 A, C$ ) and frontal cortex (Fig. 5B,D). Moreover, auto-KO mice displayed a proportionately larger increase in $5-\mathrm{HT}_{\text {ext }}$ in response to fluoxetine than their controls in the vHPC, but not in the frontal cortex ( post hoc for group, $p=0.0198$ ) (Fig. $5 C, D$ ). Together, these results demonstrate that suppression of $5-\mathrm{HT}_{1 \mathrm{~A}}$ autoreceptors throughout life results in regionally distinct increases in serotonergic tone.

Increased anxiety-like behavior in mice lacking 5-HT autoreceptors

Mice lacking all 5- $\mathrm{HT}_{1 \mathrm{~A}}$ receptors throughout life display reliably increased anxiety-like behavior (Heisler et al., 1998; Parks et al., 1998; Ramboz et al., 1998). To independently assess the role of endogenous $5-\mathrm{HT}_{1 \mathrm{~A}}$ autoreceptors and heteroreceptors in anxiety-like behavior, we tested hetero-KO, adult hetero- $\mathrm{KO}$, and auto-KO mice in conflict/anxiety paradigms: the of group in 8-OH-DPAT-treated mice, $\left.F_{(1,10)}=0.071, p=0.795\right)$ (Fig. $4 B$ ). These findings are consistent with previous literature implicating $5-\mathrm{HT}_{1 \mathrm{~A}}$ autoreceptors, but not heteroreceptors, in the 8 -OH-DPAT-induced hypothermic response in mice (Martin et al., 1992).

These results provide both a direct in vitro measurement and an in vivo confirmation of the functional selectivity of genetic suppression of $5-\mathrm{HT}_{1 \mathrm{~A}}$ autoreceptors and heteroreceptors, respectively, in the auto-KO, hetero-KO, and adult hetero-KO mice.

\section{Increased serotonergic tone in mice lacking $5-\mathrm{HT}_{1 \mathrm{~A}}$ autoreceptors throughout life}

The extracellular level of serotonin $\left(5-\mathrm{HT}_{\text {ext }}\right)$ is generally thought to be under the inhibitory control of both $5-\mathrm{HT}_{1 \mathrm{~A}}$ and $5-\mathrm{HT}_{1 \mathrm{~B}}$ autoreceptors. Here we sought to determine how specific suppression of 5- $\mathrm{HT}_{1 \mathrm{~A}}$ autoreceptors throughout life was reflected at the neurochemical level in adult animals. We observed higher basal cortical 5- $\mathrm{HT}_{\text {ext }}$ in whole-life auto-KO mice compared to their wild-type littermates $\left(F_{(1,13)}=7.79, p=0.015\right)$. However, differences between the two strains of mice in the vHPC were not significant $\left(F_{(1,13)}=1.74, p=0.21\right)($ Table 1$)$.

To directly measure the effect of pharmacological inactivation of the 5-HT transporter in mice lacking $5-\mathrm{HT}_{1 \mathrm{~A}}$ autoreceptors, we challenged both auto-KO mice and their controls with the SSRI fluoxetine.

In the frontal cortex, a two-way ANOVA (treatment by genotype) on area under the curve (AUC) values revealed no significant effect of genotype $\left(F_{(1,28)}=0.041, p=0.841\right)$, but a significant effect of treatment $\left(F_{(1,28)}=36.984, p<0.0001\right)$. No genotype-by-treatment interaction was detected $\left(F_{(1,28)}=0.02\right.$, $p=0.9672$ ).

In the vHPC, a two-way ANOVA (treatment by genotype) on AUC values revealed both a significant effect of genotype $\left(F_{(1,30)}=6.82, p=0.0139\right)$, and a significant effect of treatment $\left(F_{(1,30)}=58.21, p<0.0001\right)$, as well as a genotype-by-treatment interaction $\left(F_{(1,30)}=6.62, p=0.0153\right)$. open field, the light/dark choice test, and the elevated plus maze.

We were unable to detect any significant impact on anxietylike behavior by suppression of $5-\mathrm{HT}_{1 \mathrm{~A}}$ heteroreceptors beginning in early postnatal development. Specifically, we detected no differences between 5- $\mathrm{HT}_{1 \mathrm{~A}}$ hetero-KO mice and their controls in exploration of the center of the open field (ANOVA, $F_{(1,32)}=$ $0.025, p=0.875$ ), although a trend was seen for decreased exploration of the total open field (repeated-measures ANOVA, $F_{(1,32)}=3.31, p=0.078$ ) (Fig. $6 \mathrm{~A}$ ). Likewise, no differences were detected between $5-\mathrm{HT}_{1 \mathrm{~A}}$ hetero-KO mice and their controls in total exploration (repeated-measures ANOVA, main effect of group, $F_{(1,41)}=0.064, p=0.802$ ), entries into the light (ANOVA, main effect of group, $\left.F_{(1,41)}=0.258, p=0.614\right)$, or time in the light compartment (ANOVA, main effect of group, $F_{(1,41)}=$ $0.077, p=0.7823$ ) in the light/dark choice test (Fig. $6 B$ ). Finally, no effects on anxiety-like behavior were detected in the elevated plus maze (data not shown).

In adult hetero-KO mice, we did not detect changes in exploration of the center of the open field (ANOVA, $F_{(1,47)}=0.686$, $p=0.412$ ), although, similar to the results in hetero-KO mice, we observed a trend for a decrease in total exploration of the open field (repeated-measures ANOVA $F_{(1,47)}=2.74, p=0.105$ ) (Fig. $6 C)$. No differences were detected between adult hetero-KO mice and their controls in total exploration (ANOVA, $F_{(1,30)}=0.122$, $p=0.730)$, exploration of the light $\left(\operatorname{ANOVA}, F_{(1,30)}=2.11, p=\right.$ $0.157)$, or entries into the light in the light/dark choice test (ANOVA, $F_{(1,30)}=2.314, p=0.139$ ) (Fig. 6D). Together, these results demonstrate that suppression of $5-\mathrm{HT}_{1 \mathrm{~A}}$ heteroreceptors, beginning either in early postnatal development or adulthood, is not sufficient to impact classic anxiety-like behavior. However, we cannot rule out the contribution of $5-\mathrm{HT}_{1 \mathrm{~A}}$ heteroreceptors to exploratory behavior, as trends for decreased exploration in the open field were seen in both groups of mice that lacked 5- $\mathrm{HT}_{1 \mathrm{~A}}$ heteroreceptors.

Having observed that suppression of $5-\mathrm{HT}_{1 \mathrm{~A}}$ heteroreceptors alone, either throughout life or beginning in adulthood, was not 


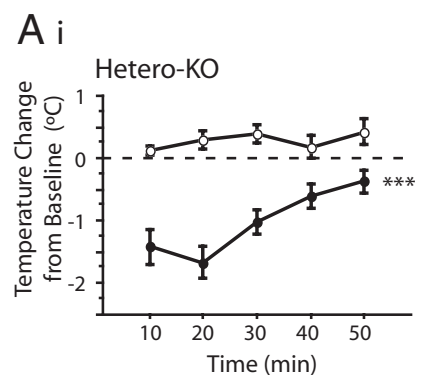

ii

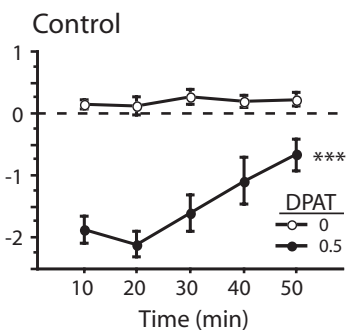

B i

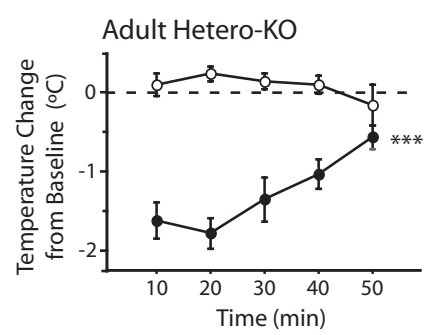

ii

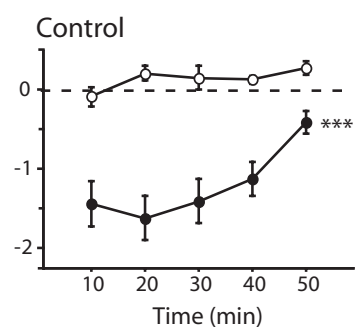

C i

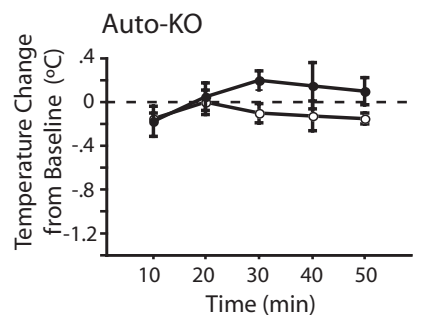

ii

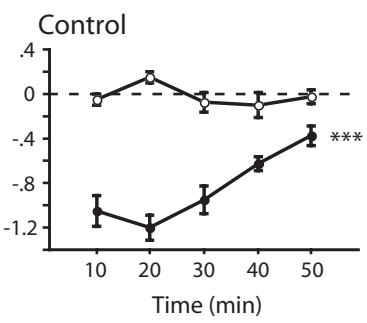

Figure 4. $\quad A$, Hypothermic response to the $5-\mathrm{HT}_{1 \mathrm{~A} / 7}$ agonist 8-OH-DPAT (DPAT) is normal in hetero-KO mice (i) and their controls (ii). $\boldsymbol{B}$, Hypothermic response to the 5-HT1A agonist 8-OH-DPAT is normal in adult hetero-K0 mice (i) and their controls (ii). C, Hypothermic response to the 5- $\mathrm{HT}_{1 \mathrm{~A}}$ agonist 8-OH-DPAT is abolished in auto-KO mice (i) and normal in their controls (ii) ( $n=3-6$ mice/group/dose). Values are mean \pm SEM. ${ }^{* * *} p<0.001$.

Table 1. Mean basal serotonin levels ( $\mathrm{fmol} / 20 \mu$ l dialysate) \pm SEM in ventral hippocampus and prefrontal cortex

\begin{tabular}{lll}
\hline & $5-\mathrm{HT}(\mathrm{fmol} / 20 \mu \mathrm{l})$ & \\
\cline { 2 - 3 } & $\mathrm{HPC}$ & $\mathrm{PFC}$ \\
\hline Control & $2.8 \pm 0.3$ & $1.9 \pm 0.1$ \\
Auto-KO & $3.7 \pm 0.5$ & $3.7 \pm 0.78^{*}$ \\
\hline
\end{tabular}

HPC, ventral hippocampus; PFC, prefrontal cortex. *Value differs from control PFC, $p=0.015$.

sufficient to impact anxiety-like behavior, we next tested whether $5-\mathrm{HT}_{1 \mathrm{~A}}$ autoreceptors alone might play a role in the establishment of anxiety-like behavior. Compared with their controls, auto-KO mice displayed decreased exploration of the center of the open field compared with the total (ANOVA, $F_{(1,50)}=8.351$, $p=0.0057$ ) (Fig. 6Eii), and a decrease in total exploration (repeated-measures ANOVA, $F_{(1,50)}=4.786, p=0.033$ ) (Fig. $5 E i)$. Likewise, in the light/dark choice test, auto-KO mice displayed decreased total exploration (ANOVA, $F_{(1,37)}=19.74, p<$ 0.0001 ) and fewer entries into the light compartment (ANOVA, $\left.F_{(1,37)}=9.19, p=0.004\right)$, but did not demonstrate a decrease in the percentage of distance in the light (ANOVA, $F_{(1,37)}=0.017$, $p=0.896$ ) (Fig. $6 F$ ). No effects on anxiety-like behavior were seen in the elevated plus maze (data not shown). The effects seen in the open field and light/dark test did not reflect an effect of dox treatment, as littermate control animals lacking the tTS transgene but fed the same chows throughout life displayed no differences

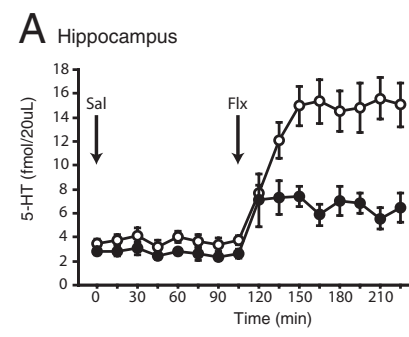

B Prefrontal Cortex
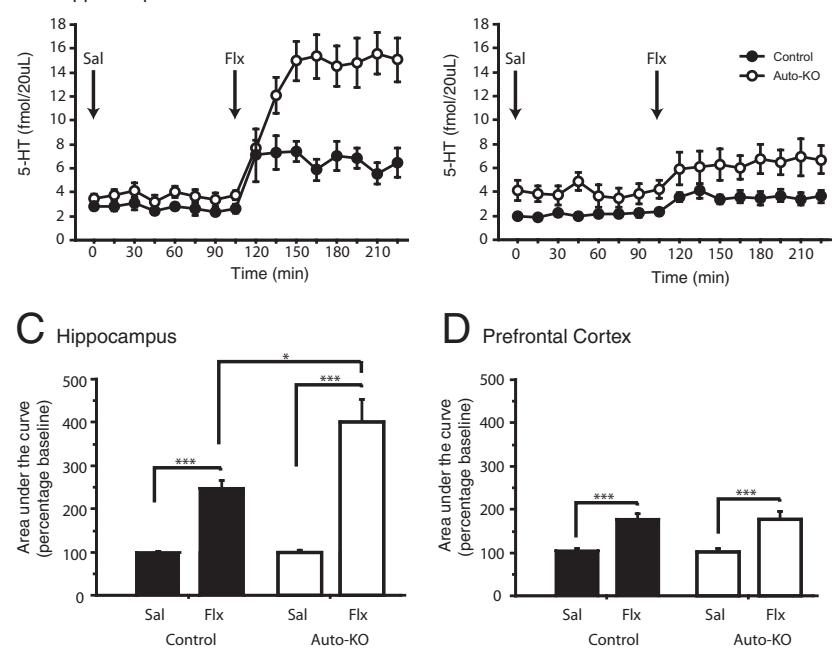

D Prefrontal Cortex

Figure 5. $\quad \boldsymbol{A}, \boldsymbol{B}$, Extracellular serotonin levels measured by in vivo microdialysis in the $\mathrm{VHPC}$ $(\boldsymbol{A})$ and PFC (B) following injection of saline (Sal; $\left.t_{0}\right)$ and $18 \mathrm{mg} / \mathrm{kg}$ fluoxetine (Flx; $\left.t_{105}\right)$. Values are mean \pm SEM for each time point. $C, D$, Total extracellular serotonin, measured by area under the curve analysis compared with baseline, increases in the $\operatorname{vHPC}(\boldsymbol{C})$ and $\mathrm{PFC}(\boldsymbol{D})$ of both auto-KO and control mice in response to acute fluoxetine treatment. Auto-KO mice display a larger percentage increase than controls in response to fluoxetine in the $\mathrm{VHPC}$ but not in the PFC. Values are \pm SEM ( $n=7-9$ mice/group). ${ }^{*} p<0.05,{ }^{* * *} p<0.001$.

in any of the measures (data not shown). The phenotype observed in auto-KO mice is consistent with the increased anxietylike behavior in conflict-based tasks and decreased exploration of novel environments, and is similar to what has been observed in constitutive 5- $\mathrm{HT}_{1 \mathrm{~A}} \mathrm{KO}$ mice on at least three genetic backgrounds (Heisler et al., 1998; Parks et al., 1998; Ramboz et al., 1998). These data suggest that endogenous $5-\mathrm{HT}_{1 \mathrm{~A}}$ autoreceptors are necessary and sufficient for the establishment of anxiety-like behavior. Furthermore, these data suggest that normal signaling though $5-\mathrm{HT}_{1 \mathrm{~A}}$ heteroreceptors (with autoreceptors intact) is dispensable for the establishment of anxiety-like behavior.

\section{Mice lacking 5-HT ${ }_{1 \mathrm{~A}}$ heteroreceptors throughout life demonstrate increased behavioral despair in the forced-swim test}

In addition to its role in anxiety, diverse evidence has linked $5-\mathrm{HT}_{1 \mathrm{~A}}$ receptors to depression and the response to stress. $5-\mathrm{HT}_{1 \mathrm{~A}} \mathrm{KO}$ mice display altered behavior in the forced-swim test (FST) and a blunted response to antidepressants as well as increased anxiety-like behavior (Ramboz et al., 1998; Santarelli et al., 2003). However, it is unclear whether the anxiety phenotype, and other non-anxiety related phenotypes like the one seen in the FST, are impacted by the same populations of $5-\mathrm{HT}_{1 \mathrm{~A}}$ receptors, or whether the temporal and spatial role of $5-\mathrm{HT}_{1 \mathrm{~A}}$ receptors for these two behaviors are distinct.

To test directly the role of 5- $\mathrm{HT}_{1 \mathrm{~A}}$ heteroreceptors and autoreceptors in mediating mood-related behavior that does not capture dimensions of anxiety, we first tested auto-KO mice in the forced swim test. In this test, which is often used as a pharmacological screen for antidepressant activity, active swimming and climbing are scored as mobility, which generally decreases over time. We observed that auto-KO mice displayed decrease mobility that was indistinguishable from their controls on the second day of testing (repeated-measures ANOVA, main effect of group, $F_{(1,48)}=0.871, p=0.3554$; main effect of time, $F_{(3,48)}=23.771$, $p<0.0001$ ) (Fig. 7C). This finding contrasted with our previ- 
A

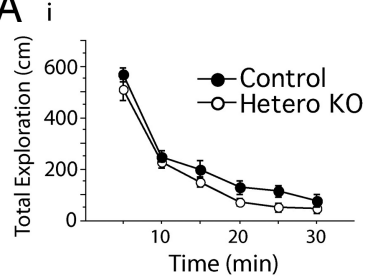

ii

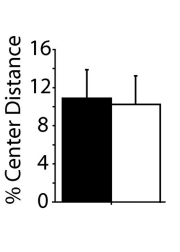

B i
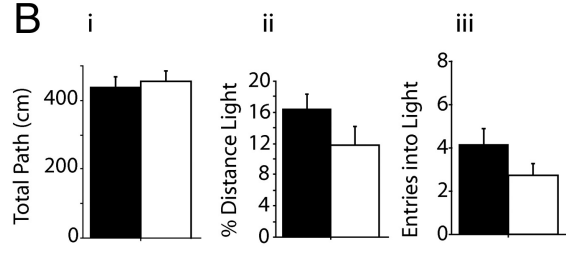

C $\mathrm{i}$
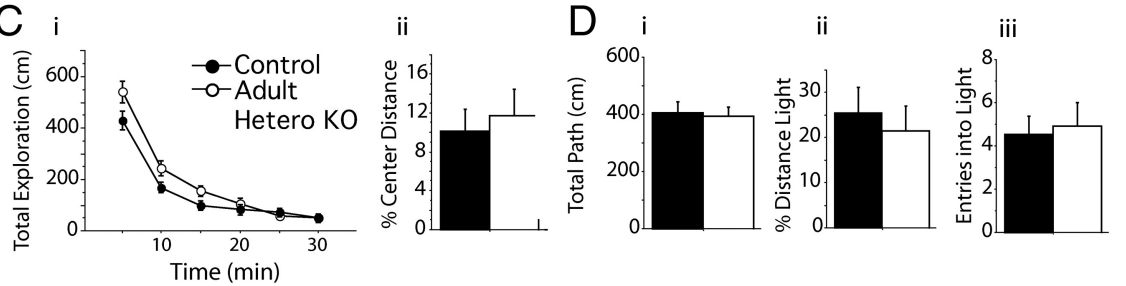

E $i$
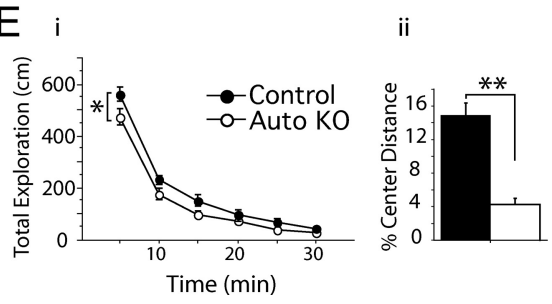

$\mathrm{F} \quad \mathrm{i}$
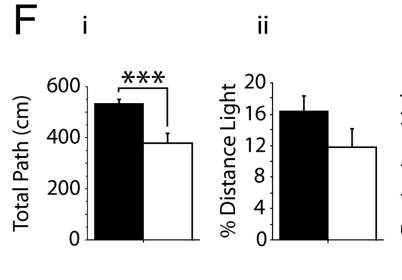

iii

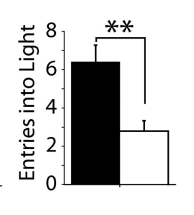

Figure 6. $A$, No group differences were detected between hetero-KO mice and their controls in the total exploration (i) or percentage exploration of the center (ii) of the open field ( $n=32$ ). $\boldsymbol{B}$, No group differences were detected between hetero-K0 mice and their controls in total exploration (i), percentage exploration of the light (ii), or entries into the light (iii) in the light/dark choice test $(n=41)$. C, No group differences were detected between adult hetero-K0 mice and their controls in the total exploration (i) or percentage exploration of the center (ii) of the open field $(n=47)$. $\boldsymbol{D}$, No group differences were detected between adult hetero-KO mice and their controls in total exploration (i), percentage exploration of the light (ii), or entries into the light (iii) in the light/dark choice test $(n=30)$. $E$, Auto-K0 mice displayed decreased total exploration $(\boldsymbol{i})$ and decreased percentage exploration of the center (ii) of the open field compared with their controls $(n=50)$. $\boldsymbol{F}$, Auto-KO mice displayed less total exploration (i) and fewer entries into the light compartment (iii), but no difference in percentage exploration of the light (ii) compared with their controls in the light/dark choice test $(n=37)$. All values are mean \pm SEM. ${ }^{*} p<0.05,{ }^{* *} p<0.01,{ }^{* * *} p<0.001$.
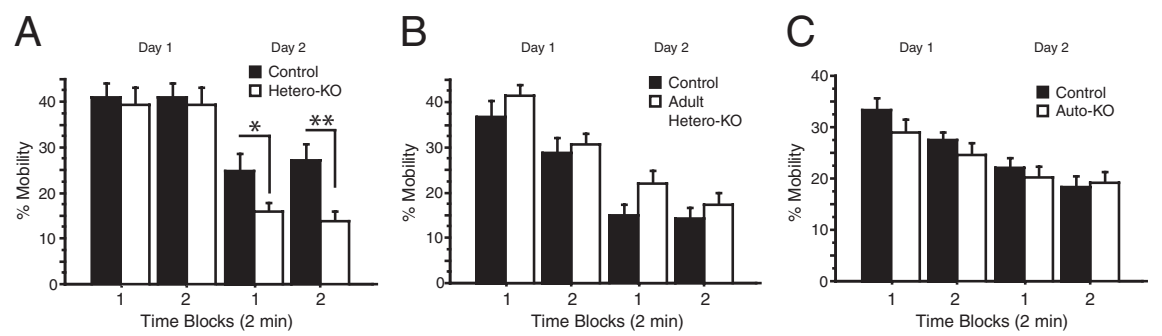

Figure 7. A, Hetero-K0 mice displayed decreased mobility compared with the their controls across a $2 \mathrm{~d}$ forced-swim test $(N=$ 48). $\boldsymbol{B}, \boldsymbol{C}$, No group differences were detected between adult hetero-KO $(\boldsymbol{B})$ or auto-KO mice $(\boldsymbol{C})$ and their controls across a $2 \mathrm{~d}$ forced-swim test $\left(N=34\right.$ and 44 , respectively). All values are mean \pm SEM. ${ }^{*} p<0.05,{ }^{* *} p<0.01$.

ously reported effect of adult suppression of $5-\mathrm{HT}_{1 \mathrm{~A}}$ autoreceptors (with decreased autoreceptor levels decreasing behavioral despair) (Richardson-Jones et al., 2010), and suggests that compensation occurs when $5-\mathrm{HT}_{1 \mathrm{~A}}$ autoreceptors are suppressed throughout life.

As suppressing autoreceptors throughout life did not alter the response to forced-swim stress, we next tested the response of hetero-KO and adult hetero-KO mice. Although hetero-KO mice were indistinguishable from their controls on the first day of testing, they displayed markedly less mobility, or more behavioral despair, on the second day of testing (repeated-measures ANOVA, group by time interaction, $F_{(3,34)}=2.97, p=0.0345$; post hoc for day 2, minutes $3-4$ and $5-6, p=0.0371$ and $p=0.0018$, respectively) (Fig. 7A). Conversely, adult suppression of $5-\mathrm{HT}_{1 \mathrm{~A}}$ het- eroreceptors was not sufficient to impact behavioral despair on either day of the test (repeated-measures ANOVA, main effect of group between adult hetero-KO mice and controls, $F_{(1,44)}=2.132, p=0.1513$; group-by-time interaction, $F_{(3,44)}=0.570$, $p=0.6357$ ) (Fig. $7 B$ ). This demonstrates that $5-\mathrm{HT}_{1 \mathrm{~A}}$ heteroreceptors act developmentally to establish the circuitry underlying this behavior, and establishes a dissociation between the roles of $5-\mathrm{HT}_{1 \mathrm{~A}}$ autoreceptors and heteroreceptors in modulating mood-related anxious and nonanxious behavior, respectively.

\section{Discussion}

\section{Independent suppression of} endogenous 5- $\mathrm{HT}_{1 \mathrm{~A}}$ autoreceptors and heteroreceptors

The $5-\mathrm{HT}_{1 \mathrm{~A}}$ receptor exists as two distinct populations in the brain (autoreceptors and heteroreceptors) that, individually, could impact the circuitry underlying mood and anxiety in both development and/or adulthood. We accomplished independent manipulation of $5-\mathrm{HT}_{1 \mathrm{~A}}$ autoreceptors and heteroreceptors populations using the tTS/tetO system (Mallo et al., 2003; Richardson-Jones et al., 2010). This system provides a number of advances over classic $\mathrm{KO}$ and previous transgenic technology. First, it allows for spatial and temporal specificity, neither of which are possible using constitutive $\mathrm{KO}$ mice. Given the hypothesized difference in the roles of the 5-HT system in development and adulthood, temporal specificity was a primary goal (Ansorge et al., 2007, 2008). Second, this genetic strategy allows for examination of the role of endogenous receptors; unlike previous transgenic overexpression strategies, the tTS/tetO strategy relies on suppressible gene expression from the endogenous promoter elements. Moreover, we have recently demonstrated that this system can be generalized to other genes (Tanaka et al., 2010).

\section{Establishment of 5-HT tone}

In agreement with the observation that the firing activity of serotonergic neurons and consequently the release of 5-HT is under tonic inhibitory control by somatodendritic $5-\mathrm{HT}_{1 \mathrm{~A}}$ autoreceptors (Haddjeri et al., 2004), constitutive deletion of the $5-\mathrm{HT}_{1 \mathrm{~A}}$ receptor increases basal extracellular 5-HT level in some brain structures (He et al., 2001; Parsons et al., 2001). This is consistent with data obtained here in auto-KO mice (Table 1). Nevertheless, the effect observed here is region-dependent, as basal $5-\mathrm{HT}_{\mathrm{ext}}$ was increased in the frontal cortex, but not in the vHPC of auto-KO mice. Several hypotheses may explain such differences. Regional differences in 5-HT reuptake sites in mouse brain could account for these neurochemical observations. Autoradiographic studies have reported a lower density of serotonin transporter (SERT) in 
the frontal cortex compared with the hippocampus in constitutive 5- $\mathrm{HT}_{1 \mathrm{~A}} \mathrm{KO}$ mice (Ase et al., 2001). Interestingly, SERT downregulation is also observed in double $5-\mathrm{HT}_{1 \mathrm{~A} / 1 \mathrm{~B}} \mathrm{KO}$ mice (Guilloux et al., 2011). Thus, the increase in $5-\mathrm{HT}_{\mathrm{ext}}$ observed in the frontal cortex (but not in the vHPC) of auto-KO mice may be attributed to a specific reduction of SERT expression in the frontal cortex. A second observation to be explored with regard to the present results is the marked difference in the intrinsic organization of 5-HT innervations. The frontal cortex is primarily innervated by the dorsal raphe nucleus (DRN), whereas the hippocampus is mostly innervated by the median raphe nucleus (MRN) (Azmitia and Segal, 1978; Imai et al., 1986; McQuade and Sharp, 1997). It is thus possible that the enhancement of basal extracellular 5-HT levels specifically in the frontal cortex in auto-KO mice resulted from a greater effect of autoreceptor deletion on the release of 5-HT from DRN compared with the MRN.

The magnitude of 5-HT release in the presence of transporter blockade also displayed a region-dependent difference. As expected, upon challenge with fluoxetine, $5-\mathrm{HT}_{\text {ext }}$ was increased in both control and auto-KO mice (Fig. 5). However, the magnitude of the response to SSRI in auto-KO mice was greater in the vHPC than in the frontal cortex. These neurochemical effects markedly contrast with levels observed at baseline. Because of the greater density of 5-HT uptake sites in the hippocampus in mice [compared with the frontal cortex (Ase et al., 2001)], SSRIs are expected to cause a greater increase in $5-\mathrm{HT}_{\text {ext }}$ levels in the hippocampus. Indeed, this was observed in the present study. In contrast with this assumption, fluoxetine (Malagié et al., 1995) and paroxetine (Romero and Artigas, 1997) have been shown to increase $5-\mathrm{HT}_{\text {ext }}$ to a comparable extent in the frontal cortex and hippocampus of wild-type mice. These data can be interpreted in light of the distinct roles that $5-\mathrm{HT}_{1 \mathrm{~A}}$ heteroreceptors in the frontal cortex are thought to play in the negative feedback inhibition of the raphe. Specifically, frontal cortex forebrain heteroreceptors are thought to participate in feedback via polysynaptic connections to the raphe, whereas hippocampal heteroreceptors are not (Ceci et al., 1994; Assié and Koek, 1996; Casanovas et al., 1999; Hajós et al., 1999). Our results in the auto-KO mouse suggest that autoreceptor feedback in response to fluoxetine is stronger in raphe projections to hippocampus than frontal cortex, since heteroreceptor-based negative feedback plays a substantial role solely in frontal cortex.

Alternatively, the heterogeneous elevation of $5-\mathrm{HT}_{\text {ext }}$ induced by fluoxetine in auto-KO mice could be due to changes in the sensitivity of terminal $5-\mathrm{HT}_{1 \mathrm{~B}}$ autoreceptors. Such changes have been detected in constitutive 5- $\mathrm{HT}_{1 \mathrm{~A}} \mathrm{KO}$ mice (Boutrel et al., 2002).

\section{Establishment of anxiety-like behavior}

Mice lacking all 5- $\mathrm{HT}_{1 \mathrm{~A}}$ receptors (both autoreceptors and heteroreceptors) throughout life display increased anxiety-like behavior (Ramboz et al., 1998). Subsequent gain-of-function experiments, in which $5-\mathrm{HT}_{1 \mathrm{~A}}$ receptors were ectopically overexpressed in forebrain areas such as the cortex and striatum (in the absence of autoreceptors), reversed the increased anxiety behavior in 5- $\mathrm{HT}_{1 \mathrm{~A}} \mathrm{KO}$ mice (Gross et al., 2002). These findings led to the theory that endogenous $5-\mathrm{HT}_{1 \mathrm{~A}}$ heteroreceptors in the forebrain control the normal establishment of anxiety-like behavior (Gross and Hen, 2004; Akimova et al., 2009; Goodfellow et al., 2009; Zhang et al., 2010). A separate body of literature has implicated serotonergic tone during postnatal development in determining anxiety-like behavior, with whole-life or early postnatal
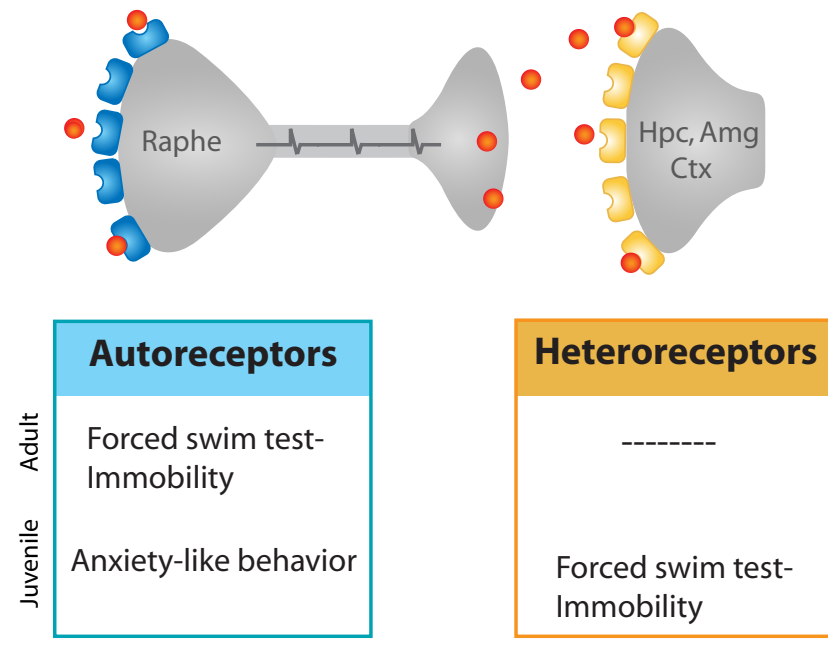

Figure 8. Schematic depicting predicted behavioral roles of endogenous 5- $\mathrm{HT}_{1 \mathrm{~A}}$ autoreceptors and heteroreceptors in the juvenile and adult mouse. Raphe autoreceptors are blue and forebrain heteroreceptors in regions, including the hippocampus (Hpc), amygdala (Amg), and cortex (Ctx), are yellow. Endogenous autoreceptors, which limit levels of serotonin released by raphe neurons, affect anxiety-related circuitry in development or circuitry mediating forcedswim test behavior in the adult. Endogenous heteroreceptors, which exert inhibitory control over certain forebrain neurons, affect forced-swim test behavior but not anxiety in the juvenile.

blockade of the 5-HT transporter increasing anxiety in rodents (Lira et al., 2003; Ansorge et al., 2004; Jennings et al., 2006). As one of the major modulators of serotonergic tone, the $5-\mathrm{HT}_{1 \mathrm{~A}}$ autoreceptors may likewise participate in the developmental establishment of anxiety. Thus, both $5-\mathrm{HT}_{1 \mathrm{~A}}$ autoreceptors and $5-\mathrm{HT}_{1 \mathrm{~A}}$ heteroreceptors are well positioned to affect the circuitry underlying anxiety-like behavior.

Here we demonstrate, using a loss-of-function approach, that suppression of endogenous 5- $\mathrm{HT}_{1 \mathrm{~A}}$ autoreceptors throughout life is sufficient to increase anxiety in the adult. Conversely, loss of endogenous heteroreceptors beginning either in the early postnatal period or in adulthood is not sufficient to impact anxietylike behavior. These results suggest that the anxious-like phenotype of the $5-\mathrm{HT}_{1 \mathrm{~A}} \mathrm{KO}$ mouse likely results from increased serotonergic neuron excitability during development. Thus, our results suggest a new framework for interpreting the role of the $5-\mathrm{HT}_{1 \mathrm{~A}}$ receptor in the developmental programming of anxiety behavior that de-emphasizes the role of the heteroreceptors in favor of autoreceptor-mediated serotonergic tone.

The results presented here by no means discount the role of serotonergic signaling in the developing forebrain in establishing anxiety circuitry. Indeed, forebrain neurons undergo a shift in their response to 5-HT during this time that corresponds to differential coupling of excitatory and inhibitory receptor subtypes (Béique et al., 2004; Goodfellow et al., 2009). Thus, the serotonergic system can impact anxiety circuitry both at the level of neurotransmitter release and through the relative balance of inhibitory and excitatory response in the developing forebrain. However, using our loss-of-function approach, we conclude that, under normal conditions, endogenous $5-\mathrm{HT}_{1 \mathrm{~A}}$ forebrain heteroreceptors are not the primary mediators of 5-HT's effect on developing anxiety circuitry. Whether these receptors might play a more prominent role under adverse conditions (i.e., with higher 5-HT as result of stress) is beyond the scope of these experiments but remains an intriguing hypothesis (Goodfellow et al., 2009).

Finally, our results highlight the importance of distinguishing between endogenous functions of a receptor (often most clearly revealed through loss-of-function manipulations) and the ability 
of a receptor to ectopically impact circuits (often most clearly revealed through gain-of-function manipulations) (Gross et al., 2002; Kusserow et al., 2004). Recent evidence suggests that the $5-\mathrm{HT}_{1 \mathrm{~A}}$ receptor has great utility in pharmacogenomic experiments designed to probe circuit function, but the phenotypes conferred by such manipulations should not be confused with the endogenous role of the receptor (Tsetsenis et al., 2007; Audero et al., 2008).

\section{Behavioral effects of heteroreceptor suppression}

In contrast to the widely recognized antidepressant effect of increasing 5-HT in the adult, several pieces of evidence suggest that increased 5-HT tone in early development can increase adult depression as well as anxiety. Although antidepressant drugs that increase extracellular 5-HT levels reliably decrease immobility in adult rodents in the forced-swim test, mice lacking 5-HT transporter activity either throughout life or only during a postnatal developmental period show increased immobility in the this test (Lira et al., 2003; Wellman et al., 2007). Moreover, mice lacking enzymes necessary for the synthesis of 5-HT throughout life (which display lower levels of 5- $\mathrm{HT}_{\text {ext }}$ ) show decreased immobility in the forced-swim test in adulthood (Savelieva et al., 2008). Thus, the circuitry underlying responsiveness in the forced swim test response can be influenced by extracellular 5-HT levels during development. Indeed, it appears that manipulations of extracellular 5-HT levels during postnatal development result in behaviors that are directly opposite to those caused by pharmacological manipulation of serotonin levels with SSRIs in adult animals.

Here we demonstrate that mice lacking $5-\mathrm{HT}_{1 \mathrm{~A}}$ autoreceptors throughout life and displaying increased anxiety-like behavior nevertheless display no differences from their controls in forcedswim behavior in adulthood. In contrast, we demonstrate that mice lacking 5- $\mathrm{HT}_{1 \mathrm{~A}}$ heteroreceptors beginning in development display decreased mobility, or increased behavioral despair, in adulthood (Fig. 8). This phenotype was not observed when heteroreceptor suppression was initiated in adulthood, suggesting that serotonergic signaling in the forebrain during development stably impacts the circuitry underlying the behavioral response to forced-swim stress without affecting conflictbased anxiety measures.

Together, our findings demonstrate a functional dissociation across both spatial (raphe vs forebrain) and temporal (development vs adulthood) domains within a single receptor subtype, and may be relevant to the partially overlapping set of genes and circuitry underlying anxiety- and depression-related behavior.

\section{References}

Adriaan Bouwknecht J, Olivier B, Paylor RE (2007) The stress-induced hyperthermia paradigm as a physiological animal model for anxiety: a review of pharmacological and genetic studies in the mouse. Neurosci Biobehav Rev 31:41-59.

Akimova E, Lanzenberger R, Kasper S (2009) The serotonin-1A receptor in anxiety disorders. Biol Psychiatry 66:627-635.

Ansorge MS, Zhou M, Lira A, Hen R, Gingrich JA (2004) Early-life blockade of the 5-HT transporter alters emotional behavior in adult mice. Science 306:879-881.

Ansorge MS, Hen R, Gingrich JA (2007) Neurodevelopmental origins of depressive disorders. Curr Opin Pharmacol 7:8-17.

Ansorge MS, Morelli E, Gingrich JA (2008) Inhibition of serotonin but not norepinephrine transport during development produces delayed, persistent perturbations of emotional behaviors in mice. J Neurosci 28:199-207.

Ase AR, Reader TA, Hen R, Riad M, Descarries L (2001) Regional changes in density of serotonin transporter in the brain of 5-HT1A and 5-HT1B knockout mice, and of serotonin innervation in the 5-HT1B knockout. J Neurochem 78:619-630.
Assié MB, Koek W (1996) Possible in vivo 5-HT reuptake blocking properties of 8-OH-DPAT assessed by measuring hippocampal extracellular 5-HT using microdialysis in rats. Br J Pharmacol 119:845-850.

Audero E, Coppi E, Mlinar B, Rossetti T, Caprioli A, Banchaabouchi MA, Corradetti R, Gross C (2008) Sporadic autonomic dysregulation and death associated with excessive serotonin autoinhibition. Science 321:130-133.

Azmitia EC, Segal M (1978) An autoradiographic analysis of the differential ascending projections of the dorsal and median raphe nuclei in the rat. J Comp Neurol 179:641-667.

Barnes NM, Sharp T (1999) A review of central 5-HT receptors and their function. Neuropharmacology 38:1083-1152.

Beck SG, Choi KC, List TJ (1992) Comparison of 5-hydroxytryptamine1Amediated hyperpolarization in CA1 and CA3 hippocampal pyramidal cells. J Pharmacol Exp Ther 263:350-359.

Beck SG, Pan YZ, Akanwa AC, Kirby LG (2004) Median and dorsal raphe neurons are not electrophysiologically identical. J Neurophysiol 91:994-1005.

Béique JC, Campbell B, Perring P, Hamblin MW, Walker P, Mladenovic L, Andrade R (2004) Serotonergic regulation of membrane potential in developing rat prefrontal cortex: coordinated expression of 5-hydroxytryptamine (5-HT)1A, 5-HT2A, and 5-HT7 receptors. J Neurosci 24:4807-4817.

Bert B, Fink H, Hörtnagl H, Veh RW, Davies B, Theuring F, Kusserow H (2006) Mice over-expressing the 5-HT(1A) receptor in cortex and dentate gyrus display exaggerated locomotor and hypothermic response to 8-OH-DPAT. Behav Brain Res 167:328-341.

Boutrel B, Monaca C, Hen R, Hamon M, Adrien J (2002) Involvement of 5-HT1A receptors in homeostatic and stress-induced adaptive regulations of paradoxical sleep: studies in 5-HT1A knock-out mice. J Neurosci 22:4686-4692.

Casanovas JM, Hervás I, Artigas F (1999) Postsynaptic 5-HT1A receptors control 5-HT release in the rat medial prefrontal cortex. Neuroreport 10:1441-1445.

Caspi A, Sugden K, Moffitt TE, Taylor A, Craig IW, Harrington H, McClay J, Mill J, Martin J, Braithwaite A, Poulton R (2003) Influence of life stress on depression: moderation by a polymorphism in the 5 -HTT gene. Science 301:386-389.

Ceci A, Baschirotto A, Borsini F (1994) The inhibitory effect of 8-OHDPAT on the firing activity of dorsal raphe serotoninergic neurons in rats is attenuated by lesion of the frontal cortex. Neuropharmacology 33:709-713.

Crawford LK, Craige CP, Beck SG (2010) Increased intrinsic excitability of lateral wing serotonin neurons of the dorsal raphe: a mechanism for selective activation in stress circuits. J Neurophysiol 103:2652-2663.

David DJ, Klemenhagen KC, Holick KA, Saxe MD, Mendez I, Santarelli L, Craig DA, Zhong H, Swanson CJ, Hegde LG, Ping XI, Dong D, Marzabadi MR, Gerald CP, Hen R (2007) Efficacy of the MCHR1 antagonist N-[3-(1-\{[4(3,4-difluorophenoxy)phenyl]methyl\}(4-piperidyl))-4-methylphen yl]-2methylpropanamide (SNAP 94847) in mouse models of anxiety and depression following acute and chronic administration is independent of hippocampal neurogenesis. J Pharmacol Exp Ther 321:237-248.

Davidson JR (2009) First-line pharmacotherapy approaches for generalized anxiety disorder. J Clin Psychiatry 70 [Suppl 2]:25-31.

Fakra E, Hyde LW, Gorka A, Fisher PM, Muñoz KE, Kimak M, Halder I, Ferrell RE, Manuck SB, Hariri AR (2009) Effects of HTR1A C(-1019)G on amygdala reactivity and trait anxiety. Arch Gen Psychiatry 66:33-40.

Franklin KBJ, Paxinos G (1997) The mouse brain in stereotaxic coordinates. San Diego: Academic.

Gartside SE, Umbers V, Hajós M, Sharp T (1995) Interaction between a selective 5-HT1A receptor antagonist and an SSRI in vivo: effects on 5-HT cell firing and extracellular 5-HT. Br J Pharmacol 115:1064-1070

Goodfellow NM, Benekareddy M, Vaidya VA, Lambe EK (2009) Layer II/III of the prefrontal cortex: inhibition by the serotonin 5-HT1A receptor in development and stress. J Neurosci 29:10094-10103.

Gross C, Hen R (2004) The developmental origins of anxiety. Nat Rev Neurosci 5:545-552.

Gross C, Zhuang X, Stark K, Ramboz S, Oosting R, Kirby L, Santarelli L, Beck S, Hen R (2002) Serotonin1A receptor acts during development to establish normal anxiety-like behaviour in the adult. Nature 416:396-400.

Guiard BP, David DJ, Deltheil T, Chenu F, Le Maître E, Renoir T, LerouxNicollet I, Sokoloff P, Lanfumey L, Hamon M, Andrews AM, Hen R, Gardier AM (2008) Brain-derived neurotrophic factor-deficient mice 
exhibit a hippocampal hyperserotonergic phenotype. Int J Neuropsychopharmacol 11:79-92.

Guilloux JP, David DJ, Xia L, Nguyen HT, Rainer Q, Guiard BP, Reperant C, Deltheil T, Toth M, Hen R, Gardier AM (2011) Characterization of 5-HT1A/1B-/- mice: an animal model sensitive to anxiolytic treatments. Neuropharmacology. Advance online publication. Retrieved April 6, 2011. doi:10.1016/J.neuroppharm.2011.02.009.

Haddjeri N, Lavoie N, Blier P (2004) Electrophysiological evidence for the tonic activation of 5-HT(1A) autoreceptors in the rat dorsal raphe nucleus. Neuropsychopharmacology 29:1800-1806.

Hajós M, Hajós-Korcsok E, Sharp T (1999) Role of the medial prefrontal cortex in 5-HT1A receptor-induced inhibition of 5-HT neuronal activity in the rat. Br J Pharmacol 126:1741-1750.

Hamon M, Gozlan H, el Mestikawy S, Emerit MB, Bolaños F, Schechter L (1990) The central 5-HT1A receptors: pharmacological, biochemical, functional, and regulatory properties. Ann N Y Acad Sci 600:114-129; discussion 129-131.

He M, Sibille E, Benjamin D, Toth M, Shippenberg T (2001) Differential effects of 5-HT1A receptor deletion upon basal and fluoxetine-evoked 5 -HT concentrations as revealed by in vivo microdialysis. Brain Res 902:11-17.

Heisler LK, Chu HM, Brennan TJ, Danao JA, Bajwa P, Parsons LH, Tecott LH (1998) Elevated anxiety and antidepressant-like responses in serotonin 5-HT1A receptor mutant mice. Proc Natl Acad Sci U S A 95:1504915054 .

Imai H, Steindler DA, Kitai ST (1986) The organization of divergent axonal projections from the midbrain raphe nuclei in the rat. J Comp Neurol 243:363-380.

Jennings KA, Loder MK, Sheward WJ, Pei Q, Deacon RM, Benson MA, Olverman HJ, Hastie ND, Harmar AJ, Shen S, Sharp T (2006) Increased expression of the 5-HT transporter confers a low-anxiety phenotype linked to decreased 5-HT transmission. J Neurosci 26:8955-8964.

Kirby LG, Pernar L, Valentino RJ, Beck SG (2003) Distinguishing characteristics of serotonin and non-serotonin-containing cells in the dorsal raphe nucleus: electrophysiological and immunohistochemical studies. Neuroscience 116:669-683.

Kirby LG, Freeman-Daniels E, Lemos JC, Nunan JD, Lamy C, Akanwa A, Beck SG (2008) Corticotropin-releasing factor increases GABA synaptic activity and induces inward current in 5-hydroxytryptamine dorsal raphe neurons. J Neurosci 28:12927-12937.

Kusserow H, Davies B, Hörtnagl H, Voigt I, Stroh T, Bert B, Deng DR, Fink H, Veh RW, Theuring F (2004) Reduced anxiety-related behaviour in transgenic mice overexpressing serotonin 1A receptors. Brain Res Mol Brain Res 129:104-116.

Le François B, Czesak M, Steubl D, Albert PR (2008) Transcriptional regulation at a HTR1A polymorphism associated with mental illness. Neuropharmacology 55:977-985.

Lemonde S, Turecki G, Bakish D, Du L, Hrdina PD, Bown CD, Sequeira A, Kushwaha N, Morris SJ, Basak A, Ou XM, Albert PR (2003) Impaired repression at a 5-hydroxytryptamine $1 \mathrm{~A}$ receptor gene polymorphism associated with major depression and suicide. J Neurosci 23:8788-8799.

Lemos JC, Pan YZ, Ma X, Lamy C, Akanwa AC, Beck SG (2006) Selective 5-HT receptor inhibition of glutamatergic and GABAergic synaptic activity in the rat dorsal and median raphe. Eur J Neurosci 24:3415-3430.

Lira A, Zhou M, Castanon N, Ansorge MS, Gordon JA, Francis JH, BradleyMoore M, Lira J, Underwood MD, Arango V, Kung HF, Hofer MA, Hen R, Gingrich JA (2003) Altered depression-related behaviors and functional changes in the dorsal raphe nucleus of serotonin transporterdeficient mice. Biol Psychiatry 54:960-971.

Lo Iacono L, Gross C (2008) Alpha-Ca2+/calmodulin-dependent protein kinase II contributes to the developmental programming of anxiety in serotonin receptor 1A knock-out mice. J Neurosci 28:6250-6257.

Malagié I, Trillat AC, Jacquot C, Gardier AM (1995) Effects of acute fluoxetine on extracellular serotonin levels in the raphe: an in vivo microdialysis study. Eur J Pharmacol 286:213-217.

Mallo M, Kanzler B, Ohnemus S (2003) Reversible gene inactivation in the mouse. Genomics 81:356-360.

Martin KF, Phillips I, Hearson M, Prow MR, Heal DJ (1992) Characterization of 8-OH-DPAT-induced hypothermia in mice as a 5-HT1A autoreceptor response and its evaluation as a model to selectively identify antidepressants. Br J Pharmacol 107:15-21.
Mayford M, Bach ME, Huang YY, Wang L, Hawkins RD, Kandel ER (1996) Control of memory formation through regulated expression of a CaMKII transgene. Science 274:1678-1683.

McQuade R, Sharp T (1997) Functional mapping of dorsal and median raphe 5-hydroxytryptamine pathways in forebrain of the rat using microdialysis. J Neurochem 69:791-796.

Nemeroff CB (2002) Comorbidity of mood and anxiety disorders: the rule, not the exception? Am J Psychiatry 159:3-4.

Oberlander TF, Gingrich JA, Ansorge MS (2009) Sustained neurobehavioral effects of exposure to SSRI antidepressants during development: molecular to clinical evidence. Clin Pharmacol Ther 86:672-677.

Olivier JD, Van Der Hart MG, Van Swelm RP, Dederen PJ, Homberg JR, Cremers T, Deen PM, Cuppen E, Cools AR, Ellenbroek BA (2008) A study in male and female 5-HT transporter knockout rats: an animal model for anxiety and depression disorders. Neuroscience 152:573-584.

Parks CL, Robinson PS, Sibille E, Shenk T, Toth M (1998) Increased anxiety of mice lacking the serotonin1A receptor. Proc Natl Acad Sci U S A 95:10734-10739.

Parsons LH, Kerr TM, Tecott LH (2001) 5-HT(1A) receptor mutant mice exhibit enhanced tonic, stress-induced and fluoxetine-induced serotonergic neurotransmission. J Neurochem 77:607-617.

Pittenger C, Huang YY, Paletzki RF, Bourtchouladze R, Scanlin H, Vronskaya S, Kandel ER (2002) Reversible inhibition of CREB/ATF transcription factors in region CA1 of the dorsal hippocampus disrupts hippocampusdependent spatial memory. Neuron 34:447-462.

Ramboz S, Oosting R, Amara DA, Kung HF, Blier P, Mendelsohn M, Mann JJ, Brunner D, Hen R (1998) Serotonin receptor 1A knockout: an animal model of anxiety-related disorder. Proc Natl Acad Sci U S A 95:14476-14481.

Ressler KJ, Nemeroff CB (2000) Role of serotonergic and noradrenergic systems in the pathophysiology of depression and anxiety disorders. Depress Anxiety 12 [Suppl 1]:2-19.

Riad M, Garcia S, Watkins KC, Jodoin N, Doucet E, Langlois X, el Mestikawy S, Hamon M, Descarries L (2000) Somatodendritic localization of 5-HT1A and preterminal axonal localization of 5-HT1B serotonin receptors in adult rat brain. J Comp Neurol 417:181-194.

Richardson-Jones JW, Craige CP, Guiard BP, Stephen A, Metzger KL, Kung HF, Gardier AM, Dranovsky A, David DJ, Beck SG, Hen R, Leonardo ED (2010) 5-HT1A autoreceptor levels determine vulnerability to stress and response to antidepressants. Neuron 65:40-52.

Romero L, Artigas F (1997) Preferential potentiation of the effects of serotonin uptake inhibitors by 5-HT1A receptor antagonists in the dorsal raphe pathway: role of somatodendritic autoreceptors. J Neurochem 68:2593-2603.

Rush AJ, Trivedi MH, Wisniewski SR, Nierenberg AA, Stewart JW, Warden D, Niederehe G, Thase ME, Lavori PW, Lebowitz BD, McGrath PJ, Rosenbaum JF, Sackeim HA, Kupfer DJ, Luther J, Fava M (2006) Acute and longer-term outcomes in depressed outpatients requiring one or several treatment steps: a STAR ${ }^{\star}$ D report. Am J Psychiatry 163:1905-1917.

Santarelli L, Saxe M, Gross C, Surget A, Battaglia F, Dulawa S, Weisstaub N, Lee J, Duman R, Arancio O, Belzung C, Hen R (2003) Requirement of hippocampal neurogenesis for the behavioral effects of antidepressants. Science 301:805-809.

Savelieva KV, Zhao S, Pogorelov VM, Rajan I, Yang Q, Cullinan E, Lanthorn TH (2008) Genetic disruption of both tryptophan hydroxylase genes dramatically reduces serotonin and affects behavior in models sensitive to antidepressants. PLoS One 3:e3301.

Tanaka KF, Ahmari SE, Leonardo ED, Richardson-Jones JW, Budreck EC, Scheiffele P, Sugio S, Inamura N, Ikenaka K, Hen R (2010) Flexible Accelerated STOP Tetracycline Operator-knockin (FAST): a versatile and efficient new gene modulating system. Biol Psychiatry 67:770-773.

Tsetsenis T, Ma XH, Lo Iacono L, Beck SG, Gross C (2007) Suppression of conditioning to ambiguous cues by pharmacogenetic inhibition of the dentate gyrus. Nat Neurosci 10:896-902.

Wellman CL, Izquierdo A, Garrett JE, Martin KP, Carroll J, Millstein R, Lesch KP, Murphy DL, Holmes A (2007) Impaired stress-coping and fear extinction and abnormal corticolimbic morphology in serotonin transporter knock-out mice. J Neurosci 27:684-691.

Zhang J, Huang XY, Ye ML, Luo CX, Wu HY, Hu Y, Zhou QG, Wu DL, Zhu LJ, Zhu DY (2010) Neuronal nitric oxide synthase alteration accounts for the role of 5-HT1A receptor in modulating anxiety-related behaviors. J Neurosci 30:2433-2441. 